\title{
The Clash of Architects: Impending Developments and Transformations in International Law
}

\author{
Joel Slawotsky \\ IDC Herzliya, Israel \\ jslawotsky@idc.ac.il
}

\begin{abstract}
The world stands at the precipice of a transitional moment in the international law writ caused by the reasonable likelihood that new architects will be joining (and eventually supplanting) the present-day architects. Transformative geo-political and economic developments such as овоR, the АІІв, NDв and the increasing internationalization of the Yuan all herald potentially significant changes to the existing international governance architecture. "Revisionist" states with strong motivations and global ambitions, may will become international law creators as these new architects influence the economic and legal orders. International law is not static and several of the new architects' customs and norms inherently conflict with current Western ideals. Will international law norms converge? Will Western notions gravitate towards the other spectrum in enlightened self-interest? The impact on international law norms, enforcement, human rights, sustainability, trade and investment treaties and arbitration will be far-reaching. Understanding how this potential re-orientations in power will affect international law is of critical importance.
\end{abstract}

\section{Keywords}

global governance architecture - international law - norms

The world stands at the precipice of a transitional moment for international law affecting both the creation and enforcement of international law; ${ }^{1}$ access

1 The dispute between China and the United States over the South China Sea provides an apt illustration. See Michael Martina, Greg Torode and Ben Blanchard, China scrambles

(C) SLAWOTSKY, JOEL, $2017 \mid$ DOI 10.1163/23525207-12340025

This is an open access article distributed under the terms of the Creative Commons Attribution- 
to financial markets; ${ }^{2}$ and global power politics. ${ }^{3}$ The reason for this historic shift is the reasonable likelihood that new creators (i.e., architects) of international law will be joining and possibly supplanting the present-day architects. ${ }^{4}$ To be an architect of international law is to wield significant power ${ }^{5}$ since the financial and legal orders are inextricably linked to the formation, context, interpretation, application and enforcement of international law. For example, powerful states (i.e., the existing architects) are rarely targets of trade sanctions, yet are uniquely positioned to employ trade sanctions against actual and/or potential rivals. ${ }^{6}$

The international legal architecture plays an integral role in the global strategic and financial orders.

However, the vocabulary for analyzing U.s. power overseas is largely military and economic, as evidenced by terms such as "gunboat diplomacy"

fighters as U.S. sails warship near Chinese-claimed reef. http://www.reuters.com/article/ussouthchinasea-usa-china-idUSKCNoY1oDM, last visit: September 12, 2017.

2 Access to global financial markets is vital to a nation's economy. The fact that the hitherto sacrosanct Swiss banking secrecy tradition was eliminated by United States threats to Swiss banks who refused to disclose the names of U.s. citizen account holders speaks volumes. See Swiss Court Says Was Right to Give U.S. Bank Data, http://www.reuters.com/article/ uk-ubs-idUKTRE76 $6 \mathrm{E}_{3} \mathrm{RH} 20110715$. Last visit: July 15, 2011. Indeed, the failure to "respect the directives of the architects" could lead to "political/financial disaster". See José E. Alvarez, Contemporary International Law: An 'Empire of Law' or the 'Law of Empire.' 24 American University International Law Review 811 (2009), p. 841.

3 For example, various U.N. humanitarian and military interventions are subject to the will of the more influential nations who are the architects of international law. Some opine that interventions are often imposed by the leading nations a form of imperialism. See Anne Orford, Muscular Humanitarianism: Reading the Narratives of the New Interventionism, 10 Eur. Journal Int'l Law 679 (1999), pp. 706-707.

4 See, e.g., U.s. Department of Defense Report, U.S. Joint Chiefs of Staff, The Joint Force in a Contested and Disordered World (2016) pp. 9, $5^{2}$.

5 Benefits accrue to the architects of international law; owning the global financial and legal orders has vested the United States with enormous power and leverage. In advocating for the Trans Pacific Partnership (“TPP”), former President Obama openly stated that the purpose of TPP was to ensure the United States rather than China set trade rules. See Andrew Hammond, The TPP gives the U.S. - rather than China - the power to influence global trade, http://news .nationalpost.com/full-comment/andrew-hammond-the-tpp-gives-the-u-srather-thanchina-the-power-to-influence-global-trade, last visit: September 12, 2017.

6 Anu Bradford \& Eric A. Posner, Universal Exceptionalism in International Law (2011). p. 51. http://www.harvardilj.org/wp-content/uploads/2011/o2/HILJ_52-1_Bradford_Posner1.pdf. Last visit: September 12, 2017. 
and "dollar diplomacy." ... The exercise of American power has been rarely based merely on the assertion of sheer economic and military might. From the beginning, it has been mediated through the language of law, as a matter of right. ${ }^{7}$

Who are the present architects of international law? The current founders of international law's global economic and legal architecture are the "civilized" or "advanced" nations of the world ${ }^{8}$ - the Western Anglo powers ${ }^{9}$ led by the United States- "the indispensable nation". ${ }^{10}$ International law architects are those nations which constitute the "civilized" nations of the world ${ }^{11}$ based upon the laws of sovereigns belonging to the group of "civilized nations of the world." ${ }^{2}$ Since the 1800 s this terminology has referred mainly to Western European nations and later in the 2oth century, to the United States and its allies. ${ }^{13}$ As Chief Architect, the United States has benefited greatly.

$7 \quad$ Economic and military power are interconnected and ensconced in international law. See Teemu Ruskola, Canton is not Boston: The Invention of American Imperial Sovereignty, 57 American Quarterly 859 (2005), p. 861.

8 The term "civilized nations" connotes a modern state which conducts itself "civilly". See Proclamation of President Sun Yat-sen on the Establishment of the Republic of China on January 1, 1912 [1912 Proclamation]. See the preamble to the 1907 Hague Convention referring to the term, "civilized nations". Gustavo Gozzi, History of International Law and Western Civilization, 9 INT'L COMM. L. REV. 353 (2007), p. 365.

9 Japan also plays a substantial role as a U.s. ally bringing great influence through the Asian Development Bank. The United States and Japan both hold 30\% of the voting power of this institution. See http://www.adb.org/about/members. Last visit: September 12, 2017.

10 President Obama has referred to the United States as "the indispensable nation." See Remarks by the President at the United States Military Academy Commencement Ceremony, https://www.whitehouse.gov/the-press-office/2014/05/28/remarks-presidentunited-states-military-academy-commencement-ceremony. Last visit: May 11, 2016. ("[T]he United States is and remains the one indispensable nation. That has been true for the century passed and it will be true for the century to come.").

11 Sosa v. Alvarez-Machain, 542 U.s. 692, 725. See also The Paquete Habana, 175 U.s. 677, 700 (1900).

12 See Statute of the International Court of Justice, Art. http://www.icj-cij.org/documents/? $\mathrm{p} 1=4 \& \mathrm{p} 2=2$. Last visit: September 12, 2017.

13 The principal United States allies are the United Kingdom and European nations such as Germany, Italy and in Western Europe but specific exceptions exist: Australia, Japan and Singapore are examples. 
The dangers of such arrogant and abusive "universalism" are especially striking in international relations, where normative disputes that cannot be resolved by rational persuasion or appeal to agreed upon international norms tend to be settled by (political, economic, and cultural) power-of which United States today has more than anyone else. ${ }^{14}$

Large swaths of "other nations" located elsewhere have traditionally been considered "uncivilized" and have thus been "outcasted" as sources of international law.

[T] he vast majority of Asian states literally did not participate in the negotiation of most of the agreements that define the modern international order ... These observations are not unique to Asia, of course. Indeed, one could make a compelling case that the disenfranchisement of African states during these formative periods of international law was far greater. ${ }^{15}$

The existing political and economic mechanics of the global financial governance order - trading, lending, development-has been dominated by the United States and U.s. led international financial institutions such as the IMF, the World Bank and the ICSID — which are all based in Washington D.C. ${ }^{16}$ In addition, the United States Dollar-the currency of the world's largest economy — has reigned supreme as the most desired currency of international

14 Critics contend that the United States has abused its unique position and has imposed its will on others. See Jack Donnelly, The Relative Universality of Human Rights, 29 Human Rights Quarterly 281 (2007), p. 305. Russian President Putin has alleged the United States has imposed its will on other nations. See Putin's Prepared Remarks at 43rd Munich Conference on Security Policy, http://www.washingtonpost.com/wp-dyn/content/ article/2007/02/12/AR2007021200555.html. Last visit: September 12, 2017.

15 See Simon Chesterman, Asia's Ambivalence about International Law: Past, Present and Futures, (2016) https://academic.oup.com/ejil/article/27/4/945/2962207/Asia-sAmbivalence-about-International-Law-and. Last visit: September 12, 2017.

16 See Larry C. Backer, International Financial Institutions (IFIs) and Sovereign Wealth Funds (SWFs) as Instruments to Combat Corruption and Enhance Fiscal Discipline in Developing States http://www.qscience.com/doi/pdf/10.5339/irl.2015.swf.5. Last visit: May 11, 2016. 
business and global trade ${ }^{17}$ and forms the principle reserve currency of the world's central banks. ${ }^{18}$

Moreover, American military power has been vigorously projected to enforce the existing architecture. Dozens of United States land, sea and air military bases are embedded strategically in a large number of nations and powerful American warships and aircraft carriers sail throughout the strategic waterways of the globe. ${ }^{19}$ No other nation's taxing authority mandates disclosure from another sovereign's financial institutions. ${ }^{20}$ No other sovereign's courts wield such power and influence. ${ }^{21}$ The judicial arm of Federal courts is extensive. ${ }^{22}$ Indeed, as with its military, the reach of U.s. justice is global. ${ }^{23}$

17 See M. J. Stephey, A Brief History of Bretton Woods System. (2008) http://content.time. com/time/business/article/o,8599,1852254,0o.html. Last visit: September 12, 2017.

18 For example, the World Bank ranks global central bank reserves in gold and us Dollars. http://data.worldbank.org/indicator/FI.RES.TOTL.CD?end=2015\&start=2015\&view=bar. Last visit: September 12, 2017.

19 Vijay Prashad, End of Exceptionalism http://www.frontline.in/world-affairs/end-ofexceptionalism/article8811042.ece. Last visit: May 11, 2016. See also List of Us military bases world-wide, List of U.S. Bases https://www.google.com/maps/d/viewer?mid=zOzzuQ7jtRM.k7KCFP1zgCAw\&hl=en_us. Last visit: September 12, 2017.

Another example of U.S. power in the financial realm is FATCA wherein foreign banks are required to report to the IRS the capital gains and income attributable to U.s. persons or risk severe penalties including lack of access to U.s. financial markets. See http://www .forbes.com/sites/robertwood/2014/08/19/ten-facts-about-fatca-americas-manifestdestiny-law-changing-banking-worldwide/\#300593551961. Last visit: September 12, 2017. The ability of the United States to essentially override domestic laws of foreign nations is exemplified by the folding of Swiss banks to U.s. demands. As recently as 2005 Swiss banking was considered a safe place to stash money anonymously. See John Grisham, The Broker, p. 366. (Noting the inviolably of Swiss banking secrecy, "the Swiss were immune to pressure from foreign governments ... they were the Swiss!"). Yet, only a few years later, the ability of the United States to enforce its taxation system on foreign financial institutions and pressurize the Swiss banks to disclose the names of account holders eliminated this anonymity. See also https://www.justice.gov/opa/ $\mathrm{pr} /$ justice-department-announces-four-banks-reach-resolutions-under-swiss-bankprogram-o. Last visit: September 12, 2017.

See Nadelle Grossman, Director Compliance with Elusive Fiduciary Duties in a Climate of Corporate Governance Reform, 12 Fordham J. Corp. \& Fin. L. 393 (2007), p. 397.

See Nine FIFA Officials and Five Corporate Executives Indicted for Racketeering Conspiracy and Corruption, https://www.justice.gov/opa/pr/nine-fifa-officials-and-five-corporateexecutives-indicted-racketeering-conspiracy-and. Last visit: September 12, 2017.

See Russia accuses us of illegal overreach with Fifa corruption indictments, http://www .theguardian.com/football/2015/may/27/russia-accuses-us-overreaching-fifa-corruptionindictments. Last visit: September 12, 2017. 
Even rivals admit that the United States is "the" superpower ${ }^{24}$ and send their children to U.s. educational institutions. ${ }^{25}$

Notwithstanding these superlative indicia of leadership, an incipient adjustment is well-underway that poses potentially serious challenges to the intellectual construct of international law being created and enforced through the lens of the present-day "civilized nations." The precipitating factor fostering these developments is the rise of "competitor states" and/or "revisionist states"-i.e., the new potential architects of international law.

A range of competitors will confront the United States and its global partners and interests. Contested norms will feature adversaries that credibly challenge the rules and agreements that define the international order. ${ }^{26}$

New builders (i.e., architects) are positioning for a significant role in shaping international law and contesting the existing global governance architecture.

Rising powers including for example, China, Russia, India, Iran, or Brazil have increasingly expressed dissatisfaction with their roles, access, and authorities within the current international system. The inability or unwillingness to accommodate the aspirations of these powers in the future may increasingly cause some states to challenge or even reject current rules and norms. ${ }^{27}$

Ramifications of the new landscape will offer striking opportunities and immense challenges in the realms of the international law writ- the defini-

24 Ilya Arkhipov, Olga Tanas, Putin Accepts U.S. as Sole Superpower While Grumbling Over NATO, http://www.bloomberg.com/news/articles/2016-06-17/putin-says-russia-wantsto-mend-ties-with-west-bears-no-grudge. Last visit: September 12, 2017.

25 See Miriam Jordan, International Students Stream Into U.S. Colleges, http://www.wsj .com/articles/international-students-stream-into-u-s-colleges-1427248801, Last visit: May 11, 2016. U.s. style of legal education is taking root overseas. See Haim Sandberg, Legal Colonialism-Americanization of Legal Education in Israel Global Jurist 10(2) (2010).

26 Referring to these rising powers as "competitors" and "revisionist" openly concedes these rising powers as potential new architects. See Defense Technical Information Center (DTIC), p. ii. http://www.dtic.mil/doctrine/concepts/joe/joe_2035_july16.pdf. Last visit: September 12, 2017 (emphasis added).

27 Defense Technical Information Center (DTIC), (2016), p. 8. http://www.dtic.mil/doctrine/ concepts/joe/joe_2035_july16.pdf. Last visit: September 12, 2017. 
tion and applicability of international law, treaty negotiation, global power balances, global trade, international monetary institutions and finance.

This transformation, currently well-underway, is enabled primarily by remarkable rising economic power. ${ }^{28}$ As will be discussed infra, the shift from strict adherence to the post Ww2 institutional frameworks such as the dominance of the IMF and World Bank, the weakening of the unchallenged premier status of the United States Dollar ${ }^{29}$ and other geo-political shifts such as the овов initiative, ${ }^{30}$ all herald potentially significant changes to the existing international legal and economic architecture. ${ }^{31}$

It would be naïve at best to presume that competitors will not contest the present architects. In fact, it would be an historical anomaly if the current legal and financial orders would not be significantly altered to comport with the advancement and furtherance of the beliefs and goals of the rising power(s).

In particular, there does not appear to be a comparable example of a great power (or multiple powers) rising within a normative framework not of its own making, where that normative framework has not undergone

28 Malcolm Scott, Here's the \$17 Trillion Reason Why the BRICS Summit This Week Is a Big Deal, (2015). http://www.bloomberg.com/news/articles/2015-07-06/here-s-the-17-trillionreason-why-the-brics-summit-this-week-is-a-big-deal. Last visit: September 12, 2017.

29 Jennifer Hughes, Patrick McGee and Jamil Anderlini, China Steps Up Currency War With Dramatic Renminbi Devaluation, http://www.ft.com/intl/cms/s/o/444c5bc8-3fca-11e59abe-5b335da3a9oe.html\#axzz3rkzgRwTv. Last visit: May 11, 2016. The Yuan had been rejected as a reserve currency in 2010 but the IMF accepted it in 2015. See http://www .bloomberg.com/news/articles/2015-11-30/imf-backs-yuan-in-reserve-currency-clubafter-rejection-in-2010. Last visit: September 12, 2017.

30 Navigate the new Silk Road, (2015). http://www.bloomberg.com/professional/blog/ navigate-the-new-silk-road/. Last visit: September 12, 2017.

31 For example, the concept of human rights is essentially a Western concept whose acceptance by the new architects is far from certain. See Jack Donnelly, Human Rights and Human Dignity: An Analytical Critique of Non Western Conceptions of Human Rights, 76 AM. POL. Sci. REv. (1982), p. 303. See also Surya P. Subedi, Are the Principles of Human Rights "Western" Ideas? An Analysis of the Claim of the "Asian" Concept of Human Rights from the Perspectives of Hinduism, 30 CAL. W. INT'L L.J. 45 (1999), p. 49. (“The absence of sufficient literature unearthing and analyzing the practices of ancient States of Asia, Africa, and other parts of the world does not signify that human rights have their origin only in Christian Western civilization."). 
substantial change or revolution as a result of the new power's values and interests. ${ }^{32}$

As former Treasury Sec. Jack Lew remarked:

The alternative [to the us led order] will be a loss of U.s. influence and our ability to shape international norms and practices that ensure an open, resilient global economy. ${ }^{33}$

This Article raises the question of how the rising prominence of "competitor" and "revisionist" states will collide with current notions and values in international law. The question poses a most serious implication for international law-a definitional moment as several of the new architects' customs and norms conflict inherently with current Western ideals. Will international law norms of the "newly civilized" converge closer to the Western ideal? Will Western notions gravitate towards the other spectrum in self-interest?

The question of how the new architects will influence international law has not been examined — nor could it — as the empowerment of the new architects is a recent phenomenon. The stakes for not addressing these issues have never been higher given the increase our inter-connected world. ${ }^{34}$ The failure to acknowledge and plan for this impending transformation will inevitably lower overall global prosperity, reduce international cooperation and possibly lead to greater military conflict. This Article proceeds as follows: Part 1 discusses the historical context of modern international law. Part 2 describes the increasing influence and power of the new architects and the impact on the existing framework. Part 3 provides examples of some new architects and the different norms these nations espouse. Part 4 examines the implications of the clash between the existing and new architects of international law.

32 Simon Chesterman, Asia's Ambivalence about International Law: Past, Present and Futures (2016), https://academic.oup.com/ejil/article/27/4/945/2962207/Asia-s-Ambivalenceabout-International-Law-and. Last visit: September 12, 2017.

33 Testimony of Secretary Lew before the House Financial Services Committee on the National Advisory Council on International Monetary and Financial Policies (2015), http://www .treasury.gov/press-center/press-releases/Pages/jl9999.aspx. Last visit:September 12, 2017. For example, with 3000 international investment treaties, the world is connected in an unprecedented fashion. 


\section{1 \\ The Historical Context of the Global Economic and Legal Orders}

Over the last 70 years, the financial and legal orders of international law have been shaped by the USA and allied Western European nations. How did certain nations become the creators of the present governance architecture? The following sub-sections provide the context and background to the existing architects of international law.

\section{1 “Civilized" Nations as Architects of International Law}

Underpinning modern international law is the foundational premise that the creation of international law is the domain of the civilized nations of the world; "the body of rules and principles of action which are binding upon civilized States in their relations with one another." 35 The term "civilized nations" is specifically listed in Article 38 of the Statute of the International Court of Justice which enumerates the sources of international law. ${ }^{36}$ Viewed favorably as an articulation of the correct foundations of international law, ${ }^{37}$ the following sources are listed:

(1) international conventions (treaties), specific or general, (2) international custom, as evidence of a general practice accepted as law, (3) general principles of law recognized by civilized nations, and (4) judicial decisions and teachings of highly regarded commentators of the various nations." 38

The vital importance of the term "civilized nations" cannot be over emphasized..$^{39}$ The notion that international law is based upon civilized states is entrenched; "the principles of international law, as they result from the usages established between civilized nations, from the laws of humanity, and

35 See J. L. Brierly, The Law Of Nations: An Introduction To The International Law Of Peace 1 (6th ed. 1963) (emphasis added). See also 4 William Blackstone, Commentaries, p. 66.

36 Statute of the International Court of Justice, Art. 38, June 26, 1945, 59 Stat. 1055, 1060.

37 See Oppenheim's International Law (Sir Robert Jennings \& Sir Arthur Watts eds., 9th ed.) (1992). p. 24.

38 Statute of the International Court of Justice, Art. 38, June 26, 1945, 59 Stat. 1055, 1060 (emphasis added).

39 For an excellent historical perspective of international law, see B. Kingsbury \& B. Straumann, The Roman Foundations of the Law of Nations: Galberico Gentili and the Justice of Empire, Oxford University Press, 2010 NYU School of Law, Public Law Research Paper, pp. 11-06. 
the requirements of the public conscience". ${ }^{40}$ For example, in The Paquete Habana ${ }^{41}$ the United States Supreme Court held that the prohibition against seizing an enemy's fishing vessels during wartime had grown over time to become established by the "general assent of civilized nations, into a settled rule of international law."42 Over 100 years later, the United States Supreme Court in Sosa v. Alvarez-Machain similarly relied upon the term "civilized nations" holding "courts should require any claim based on the present-day law of nations to rest on a norm of international character accepted by the civilized world."43

Not all countries have been treated as "civilized" nations and thus privileged to enter the realm of international law creation.

$[\mathrm{P}]$ ositivist international law distinguished between civilized states and noncivilized states and asserted further that international law applied only to the sovereign states that composed the civilized 'Family of Nations'... Jurists ... postulated a gap, understood principally in terms of cultural differences, between the civilized European and uncivilized non-European world. Having established this gap they then proceed to devise a series of techniques for bridging this gap-of civilizing the uncivilized. ${ }^{44}$

The dichotomy between nations was noted by European legal scholars ${ }^{45}$ who perceived that their nations were superior in relation to the uncivilized non-European nations. ${ }^{46}$ Therefore, the term "civilized nations" has been equated with Western European states. "([A]s a definite branch of jurisprudence the system which we now know as international law is modern, ... for

40 Preamble to Convention with Respect to the Laws and Customs of War on Land, July 29, 1899, reprinted in Texts of the Peace Conferences at the Hague, 1899 and 1907, p. 48 (James Brown Scott ed., 1908) (emphasis added).

41175 U.s. 677 (1900).

42175 U.s. 677,694 (1900) (emphasis added).

43 Sosa v. Alvarez-Machain, 542 U.s. 692, 725 (2004) (emphasis added).

44 Antony Anghie, Finding the Peripheries: Sovereignty and Colonialism in Nineteenth-Century International Law, HARV. INT'L L. 40 (1999) 1, pp. 4-5.

45 Interestingly, the earliest international law "thinkers" did not distinguish between nations. See Alexander Orakhelashvili, The Idea of European International Law, 16 Eur. J Int'l Law 315 (2006). p. 316. (Grotius treated international law as applicable to all states. Wolff also and Vattel believed the law of nations was applicable to all).

Id. p. 317 . 
its special character has been determined by that of the modern European state system." ${ }^{\text {77 }}$ The term "civilized nations" served to distinguish "superior" European ${ }^{48}$ nations from the "inferior" uncivilized nations ${ }^{49}$ and invoked to impose various legal and economic initiatives onto the "uncivilized nations." 50

European legal scholars also believed that "the rules of civilised conduct among nations applied to States within Christendom alone and that no rules of a binding nature could govern the relations of a Christian State with a nonChristian State. ${ }^{51}$ In this narrative, international law, existed for the benefit of "Christian Europe and European-originated states"52 while Buddhist, Islamic and Hindu nations were excluded. ${ }^{53}$

The exclusion of non-European states from full participation in international law was justified variously by reference to culture, religion and biology. Much of this history can be explained by racism or realpolitik. ${ }^{54}$

Evidently, certain nations were considered as simply incapable of understanding international law ${ }^{55}$ and it is not surprising that several non-Christian states were explicitly analyzed and found to be "uncivilized." "Semi-barbarous States like China, Turkey and Japan, whose municipal law and the judgments of

47 See J. L. Brierly, The Law Of Nations: An Introduction To The International Law Of Peace 1 (6th ed. 1963).

48 Id. p. 317 .

49 Id. p. 318.

5o Id.

$5^{1}$ Surya P. Subedi, Are the Principles of Human Rights "Western" Ideas? An Analysis of the Claim of the "Asian" Concept of Human Rights from the Perspectives of Hinduism, 30 CAL. W. INT'L L.J., (1999) 45, p. 59.

$5^{2}$ See Alexander Orakhelashvili, The Idea of European International Law, 16 Eur. J Int'l Law, pp. $322-323$.

53 Id. Some continue to hold this belief. See, e.g., U.s. House of Representatives Steve King echoing these sentiments and alleging that the principle contributors of civilization are Christian Europe and the United States. See https://www.youtube.com/ watch?v=medotr9q5Fs. Last visit: September 12, 2017.

54 Simon Chesterman, Asia's Ambivalence about International Law: Past, Present and Futures (2016), https://academic.oup.com/ejil/article/27/4/945/2962207/Asia-sAmbivalence-about-International-Law-and. Last visit: September 12, 2017.

55 See Alexander Orakhelashvili, The Idea of European International Law, p. 321 (citing Oppenheim). 
whose courts are not recognised by civilised nations' were excluded from full participation in international law."56

Establishing conditions for economic intercourse took the form it did because capitulations reflected the Western concept of "civilization." Capitulatory regimes were established between the United States and European countries and countries designated either "unchristian" or "uncivilized." Crudely stated, the laws of unchristian or uncivilized countries could not be the basis for determining the rights and responsibilities of persons from Christian, civilized countries. ${ }^{57}$

Labeling certain nations as uncivilized, half-civilized or savage, provided the rationalization that the civilized Europeans were in fact justified or perhaps even obligated to "civilize" inferior states via exploitation and subjugation. "More particularly, in the context of the ongoing problem of violence in the international system, it is significant that since the beginnings of international law, it is frequently the "other", the non-European tribes, infidels, barbarians, who are identified as the source of all violence, and who must therefore be suppressed by an even more intense violence." ${ }^{n 8}$ Thus, "a colonizer might need to take 'punitive expeditions' in cases of 'inroads or other outrages committed by savages of half civilised tribes." 59

Colonisation, and the reclamation of barbarians and savages, if possible in point of fact, are duties morally and jurally inevitable; and where circumstances demand the application of physical force, they fall within necessary objects of war. On this ground, the wars against China and Japan, to compel these countries to open their ports, may be defended. ${ }^{60}$

Interestingly, China was considered "uncivilized". This characterization was puzzling from the perspective of China which considered itself a magnifi-

$56 \quad$ Id. p. 319 (citing Lorimer).

57 David P. Fidler, A Kinder, Gentler System or Capitulations? International Law, Structural Adjustment Policies, and the Standard of Liberal, Globalized Civilization, 35 Texas Journal International Law (2000), p. 392.

58 Antony Anghie and B. S. Chimni, Third World Approaches to International Law and Individual Responsibility in Internal Conflicts, Chinese Journal of International Law. Vol. 2, Issue 1, (2003). p. 85 .

59 Martti Koskenniemi, The Gentle Civilizer of Nations: The Rise and Fall of International Law 1870-1960, Cambridge University Press (2001), p. 81.

$60 \quad$ J. Lorimer, The Institutes of the Law of Nations (1883), p. 28. 
cent advanced empire that defended itself against the barbarous "uncivilized" nations at its borders. ${ }^{61}$ Moreover, it is ironic that "uncivilized and barbaric" China is spearheading the current effort at creating an alternative to the current global architecture.

As discussed in the following sub-section, the concept of "civilized" nations is essentially repeated in the Restatement's definition of sources of international law. While the terminology employed is different- "major legal systems"for all intents and purposes the meaning is substantially equivalent to "civilized nations".

\section{2 "Major Legal Systems" as Architects of International Law}

The Restatement does not use the term "civilized nations" as a source of international law but rather the phrase "major legal systems."62 The terminology "major legal systems" connotes those nations which are integral to the financial and legal order, i.e., the advanced or leading nations. ${ }^{63}$ The common denominators of these "major legal systems" are: states that constitute the significant global financial and military players wielding strategic importance. Nations considered to have the major legal systems are the advanced countries that are militarily strong, economically powerful and the leaders in the arts and sciences drawing on the concept of "civilized" per Heffter - that European nations were entitled to be participants in international law based upon their immense superior power. ${ }^{64}$ Bonfils similarly linked states involved

61 See John King Fairbank, ed., The Chinese World Order:Traditional China's Foreign Relations. Cambridge, Mass.: Harvard University Press (1968).

62 A rule of international law is one that has been accepted as such by the international community of states

(a) in the form of customary law;

(b) by international agreement; or

(c) by derivation from general principles common to the major legal systems of the world (emphasis added).

63 See David, Rene \& Brieley, John E. C., Major Legal Systems in the World Today: An Introduction to Comparative Law, The Free Press $2 \mathrm{~d}$ ed (1978). (noting that the Western common law and civil law systems are the "major" legal systems); Francis Fukuyama, The End of History? The National Interest, summer 1989 https://ps321.community.uaf.edu/ files/2012/10/Fukuyama-End-of-history-article.pdf. (Noting that by the end of the 1980s, China, the former Soviet Union and the countries of Eastern Europe had all realized that the Western "advanced" nations were successful and to integrate with the world, they would need to become Westernized).

64 W. A. Heffter, Das Europäische Völkerrecht der Gegenwart (1844) pp. 14-17. 
in international law as those that are the leaders in terms of various indicia of advancement. ${ }^{65}$

This is a juridical system established by nations which demonstrated the superiority of their talents in arts, science and commerce, as well as in politics and government. Such nations are united by religion, customs and morals and ultimately by their custom of entering into treaty and diplomatic relations with one another. ${ }^{66}$

The common denominator between "civilized" and "major" is the understanding and belief that international law is created and controlled by those nations which are the "winners" in the arts, sciences, finance and law and have the military and economic power to enforce the rules and norms which constitute the international legal order. The terminology is different but essentially the "major legal systems" are the same states as defined by "civilized nations."

European countries share a host of common legal values, legal concepts, and legal institutions. There is a Western legal tradition. As Edmund Burke said, the laws of every European country are '[a]t bottom all the same,' being 'derived from the same sources.' 67

The nations presently constituting the "major legal systems" are primarily located in the Anglo Western World, mostly in the Northern Hemisphere. "Major legal systems" is therefore simply a more nuanced version of the concept of "civilized nations." 68 Regardless of the terminology-civilized or major legal system - those USA-Euro centric nations that are First World club members — rich nations that are militarily powerful — are the progenitors and enforcers of international law. ${ }^{69}$ Absent are states from "minor legal systems"

65 H. Bonfils, Manuel de Droit International Public (1894), pp. 5-6.

66 See Alexander Orakhelashvili, The Idea of European International Law, 16 Eur. J Int'l Law (2006), p. 324.

67 Harold J. Berman, Introductory Remarks: Why the History of Western Law Is Not Written, U. Ill. L. Rev. 511 (1984).

68 When developing nations develop they often look towards the Us. See Nadelle Grossman, Director Compliance with Elusive Fiduciary Duties in a Climate of Corporate Governance Reform, 12 FORDHAM J. CORP. \& FIN. L. 393, (2007), p. 397.

69 See Simon Chesterman, Asia's Ambivalence about International Law: Past, Present and Futures (2016), https://academic.oup.com/ejil/article/27/4/945/2962207/Asia-sAmbivalence-about-International-Law-and. Last visit: September 12, 2017. 
and " $[\mathrm{t}]$ here was, of course, racism present in the way some privileged (mainly European) civilization over the barbarism perceived in others". ${ }^{70}$ The ultimate outcome of "club membership" is essentially the same whether "civilized" or "major legal systems" is the benchmark used for determination.

\subsection{The Current Architects}

\subsubsection{American Post ww2 Dominance}

In the aftermath of the Second World War, the United States became the unrivalled global leader. United States led international financial institutions such as the World Bank and the IMF provided the foundations of international finance while the us Dollar was the global reserve currency. Parallel to this economic domination, America has maintained dozens of overseas military bases and its military boasts an impressive array of weapons. ${ }^{71}$ In the arts, american culture-music, cinema, sports, are sought after internationally. ${ }^{72}$ The United States is the home of the worlds' most innovative and influential companies such as Amazon, Apple, Facebook, Google, Intel, Microsoft and Twitter which have transformed the global marketplace. ${ }^{73}$ Even the U.s. law school model of legal education has taken root far from American shores ${ }^{74}$ and foreign students

$70 \quad$ Jeffrey Kahn, "Protection and Empire": The Martens Clause, State Sovereignty, and Individual Rights (2016), p.32. http://www.vjil.org/assets/pdfs/vol56/VJIL_56.1_Kahn_FINAL.pdf, last visit: September 12, 2017. See also Antony Anghie and B. S. Chimni, Third World Approaches to International Law and Individual Responsibility in Internal Conflicts, Chinese Journal of International Law 77, (2003) p. 85 (commenting that race was invoked as a rationale to characterize non Europeans as backward and barbaric).

71 Allies of the U.s. led order are generally awarded protection through U.s. military presence. See also List of us military bases world-wide. See List of U.s. Bases https://www .google.com/maps/d/viewer?mid=zOzzuQ7-jtRM.k7KCFPızgCAw\&hl=en_US, last visit: September 12, 2017.

72 See Christina Larson, The Humbling of American Tech Giants in China (2016), http://www .bloomberg.com/news/articles/2016-08-02/the-humbling-of-american-tech-giants-inchina, Last visit: September 12, 2017. (Noting that China has "an affinity for American pop culture from Titanic and Friends to Michael Jackson.").

73 See U.S. Extends Lead in International Patent and Trademark Filings (2016), http://www .wipo.int/pressroom/en/articles/2016/article_0002.html, last visit: September 12, 2017.

74 An example is the new U.s. style JD law degree program at HвKU in Qatar established in conjunction with Northwestern Law School. See Pat Vaughan Tremmel Northwestern Law Guides Creation of New Law School in Qatar (2015), http://www.northwestern.edu/ newscenter/stories/2015/02/northwestern-law-guides-creation-of-new-law-school-inqatar.html\#sthash.CFcwbCr3.dpuf, last visit: September 12, 2017. 
are eager to learn in America as U.s. education has a renowned reputation for excellence worldwide. ${ }^{75}$

However, the times, they are a changing. Sensing a weakening of the unrivalled economic, political and military status of an "American Empire"76 allegedly exhausted by wars, burdened by debt and less able to marshal the instruments of state power to protect its vital interests, other nations are stepping in, filling the power gaps and vacuums.

The global financial crisis not only caused severe hardship at home, but it also raised profound questions about the long-term viability of the us economic model and the international liberal order the United States has championed since the Second World War, particularly when juxtaposed with the perceived success of China's economy. Crisis at home and the wars in Iraq and Afghanistan generated a powerful centripetal force in the United States - a demand for greater focus within its borders rather than robust foreign policy endeavours. ${ }^{77}$

As the official statement of the BRICS conference in 2014 noted:

International governance structures designed within a different power configuration show increasingly evident signs of losing legitimacy and effectiveness. ${ }^{78}$

75 See Miriam Jordan, International Students Stream Into U.S. Colleges (2015), http://www .wsj.com/articles/international-students-stream-into-u-s-colleges-1427248801, last visit: September 12, 2017.

76 Many in the United States share this sense of decline and President Donald Trump's campaign theme of "Make America Great Again" reflect this perception. See Vijay Prashad, End of Exceptionalism, http://www.frontline.in/world-affairs/end-of-exceptionalism/article8811042.ece. Last visit: September 12, 2017. See also Carolina A. Miranda, It's Been Worn, Memed and Burned: How Donald Trump's 'Make America Great Again' Hat Reflects A Nation's Anger (2016), http://www.latimes.com/entertainment/arts/miranda/ la-ca-cam-anger-donald-trump-make-america-great-again-hat-20160706-snap-story .html, last visit: September 12, 2017.(Noting the marketing of the campaign theme).

77 Kurt Campbell and Brian Andrews, Explaining the US 'Pivot' to Asia. https://www .chathamhouse.org/sites/files/chathamhouse/public/Research/Americas/o813pp_ pivottoasia.pdf. Last visit: September 12, 2017.

78 http://pib.nic.in/newsite/PrintRelease.aspx?relid=106712. Last visit: May 11, 2016. See also Zakir Hussain Indonesian President Jokowi calls for new, more equal global economic order (2015). http://www.straitstimes.com/asia/se-asia/indonesian-president-jokowicalls-for-new-more-equal-global-economic-order, last visit: September 12, 2017. 
United States allies also sense a downsizing in the dominance of the U.s. as a sole superpower. Some have claimed that the U.s. "must face reality" and now exists in a multipolar world. ${ }^{79}$

\subsubsection{The Changing of the Guard: Taking Aim at the Indispensable Nation}

Being an architect certainly provides privileges. For example, the President of the World Bank was always an American but this has now become challenged..$^{80}$ Regarding the ADB bank-always led by a Japanese-there is also objection to the default of selecting a Japanese. ${ }^{81}$ "This de facto control of both institutions gives the United States and the EU special status that allows them to grant loans and debt relief based on geopolitical and ideological considerations." ${ }^{82}$ Similarly, while the WTO ostensibly provides member states with equal votes, nations with the most powerful economies shape and control the negotiation process. Moreover, enforcement of WTO obligations is unequal; "powerful states may violate their trade commitments toward weaker trading partners, knowing that weaker states are unlikely to carry out retaliation against them." ${ }^{\prime 3}$

Indeed, the immense leverage and power exercised by the U.s. led order vests the United States with virtual immunization from alleged violations of international law.

Although the International Court of Justice held in Nicaragua $v$. United States that the U.s. had violated Nicaragua's sovereignty under customary international law, an American veto in the UN Security Council prevented Nicaragua from enforcing the judgment in any meaningful way. ${ }^{84}$

79 https://twitter.com/gerardaraud/status/745645030824677377. Last visit: September 12, 2017.

$80 \quad J o h n$ Sinclair, Asian Development Bank presidency: looking beyond Japan (2013), http:// www.theguardian.com/global-development-professionals-network/2013/apr/22/asiandevelopment-bank-japan-president. Last visit: September 12, 2017.

81 Id.

82 Anu Bradford \& Eric A. Posner, Universal Exceptionalism in International Law, p. 50 http:// www.harvardilj.org/wp-content/uploads/2011/02/HILJ_52-1_Bradford_Posner1.pdf. Last visit: September 12, 2017 .

83 Anu Bradford \& Eric A. Posner, Universal Exceptionalism in International Law. p. 50, http://www.harvardilj.org/wp-content/uploads/2011/o2/HILJ_52-1_Bradford_Posner1.pdf. Last visit: September 12, 2017.

84 Douglas Gates, International Law Is Under Siege in the South China Sea (2017). http:// thediplomat.com/2017/o1/international-law-is-under-siege-in-the-south-china-sea/, last visit: September 12, 2017 (emphasis added). 
The leaders of China and Russia have openly remarked that the current international architecture is no longer acceptable and are increasing bilateral economic and military cooperation. ${ }^{85}$ Manifesting a clear reference to the United States, Russian leader Putin stated:

We all know that after the end of the Cold War-everyone is aware of that - a single center of domination emerged in the world, and then those who found themselves at the top of the pyramid were tempted to think that if they were strong and exceptional.... we can no longer tolerate the current state of affairs in the world ... ${ }^{86}$

The Chinese political leadership has similarly criticized the existing architecture which is perceived as inimical to Chinese national self-interest. President $\mathrm{Xi}$ has called for "a regional order that is more favorable to Asia and the world", noting that China, "[b]eing a big country means shouldering greater responsibilities for regional and world peace and development." ${ }^{87}$

Referring to the governance mechanics and rules as "a political game", China recognizes that the international law architects are vested with the privilege to dominate the world.

Western States try to impose their system, whether political or economic, on other societies. They do this through direct means such as trade and aid, or indirect means such as the monetary and economic policies imposed through the financial arms of the West-the World Bank and the International Monetary Fund. This is, and has always been, part of the political game played by the major powers to enhance their position at the world stage because it is economic dominance that they want to achieve through the imposition of their system on weaker societies. ${ }^{88}$

85 Vijay Prashad, End of Exceptionalism http://www.frontline.in/world-affairs/end-ofexceptionalism/article8811042.ece. Last visit: September 12, 2017.

86 Putin's U.N. General Assembly Speech, Sep. 28, 2015. https://www.washingtonpost.com/ news/worldviews/wp/2015/og/28/read-putins-u-n-general-assembly-speech/. Last visit: September 12, 2017.

87 Michael Schuman, Whose Money Will the World Follow? May 14, 2015, http://www .bloomberg.com/news/articles/2015-05-14/u-s-china-rivalry-whose-money-will-theworld-follow-. Last visit: September 12, 2017.

88 http://www.fmprc.gov.cn/mfa_eng/xwfw_665399/s2510_665401/t1269971.shtml. Last visit: September 12, 2017. 
As evident from the remarks of the Chinese and Russian leadership, the hegemony of the United States is being directly challenged ${ }^{89}$ with new governance heirs arguing that the West has been guilty of using "human rights issues as a tool of hegemony and power politics." ${ }^{90}$ New architects such as China have long endeavored to obtain more influence at the IFIs to reflect their growing economic strength ${ }^{91}$ and rising powers such as India perceive that they have not enjoyed meaningful power at the UN. ${ }^{92}$

Not surprisingly, the United States has not welcomed competitors to the game.

We're upholding the principle that bigger nations can't bully the smallby opposing Russian aggression, and supporting Ukraine's democracy, and reassuring our NATO allies. Well, today, it is America that stands strong and united with our allies, while Russia is isolated with its economy in tatters. That's how America leads—-not with bluster, but with persistent, steady resolve. But as we speak, China wants to write the rules for the world's fastest-growing region. That would put our workers and our businesses at a disadvantage. ${ }^{93}$

Significantly, the U.s. did not extend an invitation to China to join the (formerly us-led) TPP $^{94}$ despite being invited to join the Chinese-led АIıв. ${ }^{95}$

89 See Douglas Gates, International Law Is Under Siege in the South China Sea. Jan 21, 2017, http://thediplomat.com/2017/o1/international-law-is-under-siege-in-the-south-chinasea/. Last visit: September 12, 2017.

90 Weatherly, R., The Discourse of Human Rights in China (1999), p. 15.

91 See The infrastructure of power, The Economist, June 3oth 2016. http://www.economist .com/news/finance-and-economics/21701494-reasons-be-enthusiastic-about-chinasanswer-world-bank-infrastructure. Last visit: September 12, 2017.

92 See R.P. Anand, The Formation of International Organizations and India: A Historical Study, 23 Leiden Journal of International Law 5 (2010), p. 21. Further illustrating, India, the second most populous nation has been attempting without success to obtain a permanent seat on the UNSC. http://www.idsa.in/idsacomments/india-unsc--bid_rkumar_081216. Last visit: September 12, 2017.

93 https://www.whitehouse.gov/the-press-office/2015/01/20/remarks-president-stateunion-address-january-20-2015. Last visit: September 12, 2017.

94 http://english.cntv.cn/2015/10/10/ART114444660o6678681.shtml. Last visit: May 11, 2016.

95 http://www.gtreview.com/news/asia/xi-jinping-reiterates-us-invitation-to-aiib/. Last visit: September 12, 2017 . 
Chinese proposed reforms of the IMF that would have enhanced China's importance in the IMF have been routinely rejected. ${ }^{96}$ In a sense "Washington's reluctance to make room for China at the table of power may have convinced the leaders of the People's Republic they are unwelcome at America's dinner party" 97 and encouraged China to offer an alternative architecture.

This has substantially incentivized the interest in developing alternative rules and institutions and thus attempts to develop a viable option to replace the current architecture is not surprising. "The use of financial instruments of power by the West to disconnect revisionist states will increase their incentive to pursue alternative political and economic arrangements." 98

Interestingly, the dissatisfaction with the existing international governance architecture is not new. Asian nations have previously attempted to address this perception of an unfair governance order imposed by the Western powers. ${ }^{99}$ The "uncivilized" or "non-advanced" nations endeavored to alter the governance architecture writ in general and the international law order in particular with the 'New International Economic Order" seeking to promote an alternative international law, trade and investment regime.

Just as important as the NIEO's economic objectives were the novel means it sought to implement its objectives through new mechanisms of international law. Rather than accepting international law as a neutral device, NIEO legal theorists claimed that existing international law, unsuited to promoting structural reform, was biased toward economic incumbents and needed recasting in order to favor developing nations. More narrowly, NIEO proponents argued that states in the south should not be bound by legal agreements made under an illegitimate transnational legal regime, particularly if those agreements had been concluded by pre-independence administrations or with private corporations. Just

96 See Paola Subacchi, American Leadership in a Multipolar World, http://www .project-syndicate.org/commentary/china-united-states-global-governance-by-paolasubacchi-2015-04. Last visit: September 12, 2017.

97 Michael Schuman, Whose Money Will the World Follow? May 14, 2015, http://www .bloomberg.com/news/articles/2015-05-14/u-s-china-rivalry-whose-money-will-theworld-follow-. Last visit: September 12, 2017.

98 Defense Technical Information Center (DTIC), p. 8. http://www.dtic.mil/doctrine/ concepts/joe/joe_2035_july16.pdf. Last visit: September 12, 2017.

99 See Luis Eslava, Michael Fakhri and Vasuki Nesiah (eds.) Bandung, Global History and International Law: Critical Pasts and Pending Futures. http://www.academia.edu/10009133/ Bandung_Global_History_and_International_Law_Critical_Pasts_and_Pending_Futures_ Forthcoming_CUP_Introduction. Last visit: September 12, 2017. 
as the economic goal of the NIEO was to enable the self-sufficiency and self-determination of countries in the south, the legal strategy was similarly predicated on the bedrock assertion of the absolute sovereign equality of every nation..$^{100}$

Another example was the South American drive in the late 196os to establish a rival to the World Bank "as a way of bypassing the stringent rules imposed by the World Bank on infrastructure loans."101 Yet another example was the early 2000 s endeavor of Asian states known as the Chiang Mai Initiative to establish a network of currency swap agreements to address objections to the IMF. ${ }^{102}$ And in 2009 Latin American nations agreed to establish the "Bank of the South" to remedy perceived inequality at the established IFIs. ${ }^{103}$

In evaluating the current drive to alter the U.s.-led order, it is instructive to note another failed effort to dethrone the American hegemony: during the Cold War years, the former Soviet Union was indeed an ideological rival to the United States. However, in hindsight, it never represented a true threat to America's position as Chief Architect. Why did the Soviets fail and what can it inform us of the current drive?

The Soviet failure to achieve its goal was caused by serious weaknesses in the realms of finance, technology and self-sufficiency. As President Reagan noted:

In the 1950's, Khrushchev predicted, "We will bury you." But in the West today, we see a free world that has achieved a level of prosperity and wellbeing unprecedented in all human history. In the Communist world, we see failure. Technological backwardness. Declining standards of health. Even want of the most basic kind - too little food. Even today, the Soviet Union still cannot feed itself. ${ }^{104}$

The Soviets were always on the "outside looking in" predicting America's demise but contributing nothing more than flamboyant rhetoric, propaganda,

\footnotetext{
100 See Nils Gilman, The New International Economic Order: A Reintroduction (2015), http:// humanityjournal.org/issue6-1/the-new-international-economic-order-a-reintroduction/. Last visit: September 12, 2017 .

101 See Raj M. Desai and James Raymond Vreeland What the New Bank of BRICS Is All About https://www.washingtonpost.com/news/monkey-cage/wp/2014/07/17/what-the-newbank-of-brics-is-all-about/. Last visit: September 12, 2017.

102 Id.

103 Id.

104 http://www.nytimes.com/1987/06/13/world/excerpts-from-reagan-s-talk-at-the-berlinwall.html. Last visit: September 12, 2017.
} 
military flashpoints and support for anti-Western dictators and "revolutionary groups". ${ }^{105}$ The Soviets never undertook to assemble a potentially alternative architecture or to become a rule setter. The Soviet plan to dethrone America failed miserably. The Soviets never assembled an alternate architecture to the global governance order as China and other competitors have done.

Will China, India, and several other competitors or revisionists, i.e., the budding new architects succeed in contrast to the prior failed attempts at rewriting the international governance architecture? The current prospect is different from prior attempts at undermining American global leadership in several crucial aspects.

First, while China is the spiritual leader of the new architects, several other significant players are now allied with China. Unlike the Soviet Union, whose main allies were failed communist states with stagnant economies and little or no influence on the governance architecture, China's allies are set to become some of the largest global economies in the near future. ${ }^{106}$ The BRICS certainly have the global economic clout to become vital global economic players. "The total annual output of [the BRICs] has spiraled in recent years, to an astonishing $\$ 29.6$ trillion (£17.3 trillion) last year on a PPP-basis adjusted for living costs. That's within spitting distance of the $\$ 34.2$ trillion generated by the us and European Union combined."107 With respect to China alone, its rise has been enormous and it currently stands as the world's second biggest economy.

America's GDP, incidentally, was $\$ 16.8$ trillion on World Bank numbers, and China's was $\$ 16.2$ trillion-within a whisker of knocking the us off its perch. The balance of global economic power is on a knife-edge. ${ }^{108}$

While the U.s. remains number one, China has moved into second place with India number four-close to surpassing Japan. ${ }^{109}$ China's economic rivalry

105 See http://www.unc.edu/depts/diplomat/archives_roll/2003_04-06/covarrubias_us/ covarrubias_us.html\#text22. Last visit: September 12, 2017.

106 http://www.nextbigfuture.com/2017/02/price-waterhouse-updates-gdp.html. Last visit: September 12, 2017.

107 http://www.telegraph.co.uk/finance/comment/liamhalligan/10978178/The-dollars-70year-dominance-is-coming-to-an-end.html. Last visit: May 11, 2016.

108 Id.

109 Joel Slawotsky, The Virtues of Shareholder Value Driven Activism: Avoiding Governance Pitfalls, 12 Hastings Business Law Journal 521 (2016), p. 555. 
with the USA for global supremacy is already in play. ${ }^{110}$ In a remarkably short span, less than 15 years, the us economy has experienced a relatively huge decline vis a vis China.

Whether the United States could lead in each of three areas-military, economic, and soft power-is questionable. China by some measures is set to overtake the United States as the world's leading economic power. A recent estimate in Bloomberg shows that in 2001, America's GDP (\$10.6 trillion) was eight times that of China's. By 2015, the American GDP was only 1.6 times China's $-\$ 18$ trillion to China's $\$ 11.4$ trillion. ${ }^{111}$

To put the decline into perspective, total GDP of the United States in 2001 was nearly equal to GDP of the following six top nations combined. ${ }^{112}$ Indeed, China has already eclipsed the United States as the largest trading nation. ${ }^{113}$

Get ready for a new economic order. In the world 15 years from now, the U.s. will be far less dominant, several emerging markets will catapult into prominence, and some of the largest European economies will be slipping behind. ${ }^{114}$

In addition, nations located in Asia and Africa are slated to become substantially more important over the next $10-15$ years.

China's GDP will grow to more than twice its size today, helping the Asian powerhouse to almost entirely close its gap with the U.s.

Countries with the biggest advances ... are concentrated in Africa, Asia and the Middle East. ${ }^{115}$

110 See Malcolm Scott and Cedric Sam, China and the United States: Tale of Two Giant Economies (2016), http://www.bloomberg.com/graphics/2016-us-vs-china-economy. Last visit: September 12, 2017 .

111 See http://nationalinterest.org/feature/american-primacy-multiplex-world-17841. Last visit: September 12, 2017 .

112 World Development Indicators database, World Bank, (2002). http://www/worldbank .org/data/countrydata/countrydata.html. Last visit: May 11, 2016.

113 China Eclipses U.S. as Biggest Trading Nation (2013), http://www.bloomberg.com/news/ articles/2013-02-09/china-passes-u-s-to-become-the-world-s-biggest-trading-nation. Last visit: September 12, 2017.

114 http://www.bloomberg.com/news/articles/2015-04-10/the-world-s-20-largest-economiesin-2030. Last visit: September 12, 2017.

115 Id. 
China is at the center of a booming Asia which is home to the fastest growing nations with immense populations and potential economic output.

[A] future Shanghai Cooperation Organization (sco) could represent up to half of the world's population, 35 percent of global economic output, and account for nearly 20 percent of the world's oil production. ${ }^{116}$

China is also the Chief Architect of овов (discussed infra); the sheer economic size of the hub of alliances would involve over 4 billion people with a collective GDP of over 2 trillion USD. ${ }^{117}$ ОвоR includes the energy rich Middle East where per capita GDP and per capita wealth are among the world's highest. For example, out of the top richest states on the basis of the percentage of per capita millionaires, the oil and gas rich Middle East dominates: United Arab Emirates, Saudi Arabia, Bahrain, Kuwait, Israel and Qatar Emirates. ${ }^{118}$

Second, unlike China, the Soviets never really set forth an ambition to integrate into the existing order and/or establish an alternative vision. The Soviets were outliers or outcasts. In contrast, China has embraced globalization and economic partnership and is leading the charge on climate change. ${ }^{119}$ China has already advanced the prospect of a reduced global American role to a far greater extent by masterfully integrating - and immensely benefiting fromglobalization and free trade. Indeed, an impressive array of metrics indicates that China is a bonafide rival "of equals" to the United States. China is the lone nation that can wield enough military power to openly confront the United States ${ }^{120}$

116 Defense Technical Information Center (DTIC), p. 8, http://www.dtic.mil/doctrine/ concepts/joe/joe_2035_july16.pdf. Last visit: September 12, 2017.

117 See https://www.bloomberg.com/news/articles/2016-08-07/china-s-marshall-plan. Last visit: September 12, 2017.

118 https://www.bcgperspectives.com/content/articles/financial_institutions_business_ unit_strategy_global_wealth_2014_riding_wave_growth/?chapter=2\#chapter2_section3. Last visit: May 11, 2016. (ranking Qatar \#1, Kuwait \#5, Bahrain \#6, Israel \#8, Oman \#10, UAE \#12 and Saudi Arabia \#13). See also Ex-UBS Bankers Target Israeli Millionaires With Wealth Broker, https://www.bloomberg.com/news/articles/2017-02-27/ex-ubs-bankerstarget-israeli-millionaires-with-wealth-broker. Last visit: September 12, 2017. ("The number of Israeli millionaire households rose 17 percent last year to about 162,000, according to Boston Consulting Group. To serve this growth, there are now about 100 private banks and family offices in [the] country.").

119 http://foreignpolicy.com/2017/02/24/only-china-can-save-the-planet/. Last visit: September 12, 2017.

120 See http://thediplomat.com/2017/o1/international-law-is-under-siege-in-the-southchina-sea/. Last visit: September 12, 2017. 
and a recent comprehensive analysis ${ }^{121}$ indicates that China's military is close to reaching parity with the Western powers. ${ }^{122}$ Aside from military empowerment, China is also investing substantially in education ${ }^{123}$ and is attempting to rival Western academic institutions. ${ }^{124}$ In the most vital technological spheres of the coming decades, robotics, space exploration and artificial intelligence, Chinese aspirational hegemony is self-evident. ${ }^{125} \mathrm{~A}$ Chinese White Paper envisions China as the most powerful space nation ${ }^{126}$ and China is indeed on course to achieve a relative parity or perhaps superiority to the United States exploration. ${ }^{127}$ NASA concedes China is a serious contender for global leadership in space. ${ }^{128}$

Third, Chinese leadership on several impressive economic and geo-political initiatives. The Soviet Union's failure to exercise influence on the global governance architecture stands in stark contrast to China's global initiatives such as the АІІв, овов, Yuan internationalization and other efforts at both supplementing and potentially supplanting the existing architecture.

Fourth, adding credibility to the potential transformation of the governance architecture, the impetus for change is not solely the non-Western states; some

\footnotetext{
121 See http://www.iiss.org/en/publications/military-s-balance. Last visit: September 12, 2017.

122 See http://www.japantimes.co.jp/news/2017/02/15/asia-pacific/chinese-weaponswarplanes-reaching-near-parity-west-study. Last visit: September 12, 2017.

123 See http://www.nytimes.com/2013/01/17/business/chinas-ambitious-goal-for-boom-incollege-graduates.html. Last visit: September 12, 2017.

124 See https://www.theguardian.com/education/2010/feb/o2/chinese-universities-willrival-oxbridge. Last visit: May 11, 2016.

125 See Paul Mazur, Beijing Wants A.I. to Be Made in China by 2030, (2017) https://www.nytimes .com/2017/07/20/business/china-artificial-intelligence.html. Last visit: September 12, 2017. ("The country laid out a development plan on Thursday to become the world leader in A.I. by 2030, aiming to surpass its rivals technologically and build a domestic industry worth almost $\$ 150$ billion. Released by the State Council, the policy is a statement of intent from the top rungs of China's government: The world's second-largest economy will be investing heavily to ensure its companies, government and military leap to the front of the pack in a technology many think will one day form the basis of computing.").

126 See http://www.spaceref.com/news/viewsr.html?pid=49722. Last visit: September 12, 2017.

127 See http://nationalinterest.org/blog/the-buzz/parity-beginning-emerge-betweenamerica-china-space-16844. Last visit: September 12, 2017.

128 See https:/www.bloomberg.com/graphics/2016-asia-space-race/china.html. Last visit: September 12, 2017. Another potential new architect, India is also rapidly expanding its technological prowess. See http://timesofindia.indiatimes.com/india/indias-record-satellitelaunch-ramps-up-space-race-chinese-media/articleshow/57248903.cms. Last visit: September 12, 2017.
} 
Western nations have been alluding to a needed "re-assessment" of the current governance architecture. ${ }^{129}$

'Europe wants it. Europe demands it. Europe will get it.' The "it" here is global financial reform ... Just hours after their closed-door meeting had finished, Bush and Sarkozy, along with European Commission President Jose Manuel Barroso, issued a joint statement announcing that a summit would be held next month to devise what Barroso calls a "new global financial order. ${ }^{130}$

The willingness of U.s. allies to "join the other team" over U.s. opposition and join the AIIB is a signal that U.s. dominance is under active challenge from within the existing architects. "Many U.S. allies joined the Asian Infrastructure Investment Bank (AIIB) []—despite Washington's initial objections—in what was seen as a major diplomatic victory for President Xi Jinping."131 What is striking is that us allies such as Australia and South Korea, who were urged not to join the Chinese led AIIB — and who initially listened to the intensive US lobbying ${ }^{132}$ - eventually joined the AIIB $^{133}$ in a move widely understood as a blow to U.s. prestige and influence. ${ }^{134}$

129 Indeed, the ImF itself inareportfound that thepolicies of theIMF andWorld Bankhavefailed and are not working. See http://www.imf.org/external/pubs/ft/fandd/2016/o6/ostry.htm. Last visit: September 12, 2017. See also http://www.independent.co.uk/news/uk/politics/neoliberalism-is-increasing-inequality-and-stunting-economic-growth-the-imfsays-a7052416.html. Last visit: September 12, 2017.

130 See M. J. Stephey A Brief History of Bretton Woods System. Last visit: September 12, 2017.

131 Simon Denyer, China launches development bank for Asia, calls it first step in 'epic journey' (2015), https://www.washingtonpost.com/world/china-launches-infrastructure-bankfirst-step-in-an-epic-journey/2015/o6/29/e7d8bd7a-can1-46fa-9bad-15ba856f958c_story .html. Last visit: September 12, 2017.

132 John Kemp, China's Silk Road challenges U.S. dominance in Asia, http://www.japantoday .com/category/opinions/view/chinas-silk-road-challenges-u-s-dominance-in-asia Nov 14, 2014. Last visit: September 12, 2017.

133 See More Countries Say to Join China-Backed AIIB Investment Bank, http://www.reuters .com/article/2015/03/28/asia-aiib-china-idUSL2NoWUo2R20150328\#EwA1M3FhXwA5I YkH.99, Last visit: May 11, 2016. See also Ankit Panda, South Korea Joins the AIIB http:// thediplomat.com/2015/03/south-korea-joins-the-aiib/. Last visit: September 12, 2017.

134 Ian Talley, Obama: We're All for the Asian Infrastructure Investment Bank, http://blogs.wsj .com/economics/2015/04/28/obama-were-all-for-the-asian-infrastructure-investmentbank. Last visit: September 12, 2017. 
Representatives from Britain, Germany, South Korea and Australia were among those who took part in a ceremony to sign the articles of association in the Great Hall of the People, with the United States and Japan the most notable absentees. ${ }^{135}$

U.S. allies perceive that China is becoming an integral pillar of the financial architecture. As the Governor of the Bank of England commented "London is growing rapidly as a centre for вмв business. The establishment of a sterlingrenminbi swap line will support UK domestic financial stability."136

In sum, the previously "less civilized/advanced" nations are increasingly becoming players in the military, ${ }^{137}$ financial, ${ }^{138}$ technological ${ }^{139}$ and scientific research spheres. ${ }^{140}$ Accordingly, the "uncivilized" and "less advanced" nations are now poised to become the new architects and are now in a position to deploy for their own purposes those instruments of which they previously been victims. Dissatisfaction with the existing governance order is not new

135 Simon Denyer, China launches development bank for Asia, calls it first step in 'epic journey' (2015), https://www.washingtonpost.com/world/china-launches-infrastructure-bankfirst-step-in-an-epic-journey/2015/06/29/e7d8bd7a-ca11-46fa-9bad-15ba856f958c_story .html. Last visit: September 12, 2017.

${ }_{13}$ See People's Bank of China Swap Line, http://www.bankofengland.co.uk/publications/ Pages/news/2013/033.aspx Feb 22, 2013. Last visit: September 12, 2017.

137 See http://thediplomat.com/2017/01/international-law-is-under-siege-in-the-southchina-sea/. Last visit: September 12, 2017. See also http://www.iiss.org/en/publications/ military-s-balance. Last visit: September 12, 2017. Colin Chocola Russia Flexes Military Muscle By Patrolling United States Border With Long Range Bombers (2016), http://ijr .com/2014/11/201915-russia-starts-flying-near-us-border/. Last visit: September 12, 2017.

138 See Divya Lulla and JahanZaib, Mehmood Chaudhary and Maria Tor, Largest 100 Banks In The World (2015), https://www.snl.com/InteractiveX/Article.aspx?cdid=A-33361429-13866. Last visit: September 12, 2017. (Chinese banks are among the world's largest.).

139 See Christina Larson, The Humbling of American Tech Giants in China (2016), http://www .bloomberg.com/news/articles/2016-08-02/the-humbling-of-american-tech-giants-inchina. Last visit: September 12, 2017 (noting that Chinese technology companies are beginning to produce rival products and services that match or are superior to us companies). See Paul Mazur, Beijing Wants A.I. to Be Made in China by 2030 (2017), https://www.nytimes .com/2017/07/20/business/china-artificial-intelligence.html. Last visit: September 12, 2017. See http://timesofindia.indiatimes.com/india/indias-record-satellite-launch-ramps -up-space-race-chinese-media/articleshow/57248903.cms. Last visit: September 12, 2017.

140 See Yingying Zhou, The Rapid Rise of A Research Nation http://www.nature.com/ nature/journal/v528/n7582_supp_ni/full/528S170a.html?foxtrotcallback=true. Last visit: September 12, 2017. (noting the tremendous growth in Chinese research and scientific achievement). 
as us led institutions have come under increasing criticism due to the perceived "American" dominance. "Dissatisfaction with the current set of international rules, norms, and agreements will cause revisionist actors to make their own - and attempt to enforce them."141 Previous attempts were unsuccessful but as outlined above, China is rich and powerful, has integrated and has successful allies. These factors substantially increase the chances of a successful implementation of an alternative structure. The next section will detail these developments.

International law norms are substantially influenced, shaped and perhaps dictated by the Golden Rule-he who owns the gold; makes the rules. For approximately 70 years, the United States imprimatur on the global order has been undeniable and has resulted in a virtually unchallengeable hegemony. As former President Obama remarked:

In fact, by most measures, America has rarely been stronger relative to the rest of the world ... Our military has no peer ... Meanwhile, our economy remains the most dynamic on Earth; our businesses the most innovative. Each year, we grow more energy independent. From Europe to Asia, we are the hub of alliances unrivaled in the history of nations.... So the United States is and remains the one indispensable nation. That has been true for the century passed and it will be true for the century to come. ${ }^{142}$

The backdrop to American supremacy lies in the Bretton Woods agreement which effectively conferred the prize of global economic leadership on the United States. The agreement served as the backdrop to the development of an institutional framework which was created, shaped and influenced by the United States in unrivalled fashion. Through these international financial institutions, particularly the IMF and World Bank, loans and credit are supplied, international transactions are consummated and paid for, wealth is stored by central banks and trade disputes are resolved. In sum, these mecha-

141 Defense Technical Information Center (DTIC), p. 21. http://www.dtic.mil/doctrine/ concepts/joe/joe_2035_july16.pdf. Last visit: September 12, 2017.

142 See https://www.whitehouse.gov/the-press-office/2014/05/28/remarks-president-unitedstates-military-academy-commencement-ceremony. Last visit: September 12, 2017. 
nisms facilitate global commerce and enable nations to either prosper or fail economically. Both the IMF and World Bank are ideologically "pro-western" and operated in a decidedly pro-USA context with U.S. allied countries receiving preferential terms and lending amounts. ${ }^{143}$ The institutional frameworks were developed with no input from the "uncivilized" such as China and India ${ }^{144}$ "reflect[ing] the distribution of power at that time, which disproportionally favored the United States and the European states." 145 The overwhelming dominance of the U.S. allied coalition of architects is clear: the United States wields nearly seventeen percent of the votes and the Europeans control forty percent of the vote with a mere five percent aggregate voting share for China and India. ${ }^{146}$

But, the times, they are a changing. Referring to China's move to establish a rival development bank, former U.s. Treasury Secretary Summers called 2015 "the moment the United States lost its role as the underwriter of the global economic system". ${ }^{147}$

I can think of no event since Bretton Woods comparable to the combination of China's effort to establish a major new institution and the failure of the us to persuade dozens of its traditional allies, starting with Britain, to stay out of it. ${ }^{148}$

The following sub-sections describe these new developments.

143 See Helen Milner, Globalization, Development, and International Institutions: Normative and Positive Perspectives, p. 839. http://faculty.georgetown.edu/jrv24/milner_05.pdf. Last visit: September 12, 2017. See also Catherine Gwin, U.S. relations with the World Bank, 1945-1992, in Kapur, Devesh, Lewis, John P., Webb, Richard. 1997. The World Bank, Its First Half Century, Volume 2, p. 195.

144 China's Yuan Replacing US Dollar As Global Currency: A Not So Distant Prospect-Analysis (2016), http://www.eurasiareview.com/04052016-chinas-yuan-replacing-us-dollar-asglobal-currency-a-not-so-distant-prospect-analysis/. Last visit: September 12, 2017.

145 See Anu Bradford \& Eric A. Posner, Universal Exceptionalism in International Law, p. 50. http://www.harvardilj.org/wp-content/uploads/2011/o2/HILJ_52-1_Bradford_Posner1.pdf. Last visit: September 12, 2017.

146 Id. Last visit: September 12, 2017.

147 Time Us leadership woke up to new economic era (2015), http://larrysummers.com/ 2015/04/05/time-us-leadership-woke-up-to-new-economic-era/. Last visit: September 12, 2017.

148 Time us leadership woke up to new economic era (2015), http://larrysummers.com/ 2015/04/05/time-us-leadership-woke-up-to-new-economic-era/. Last visit: September 12, 2017. 


\subsection{China's New Development Bank-The AIIB}

It "is natural that when nations become more prosperous and more powerful, they try to find their own independent role and place in the galaxy of nations." ${ }^{49}$ China is promoting "a regional order that is more favorable to Asia and the world" and noting that China, "[b]eing a big country means shouldering greater responsibilities for regional and world peace and development."150 As a counter balance to the IMF, World Bank and ADB, China has launched a Chinese-led institution - the АІв . ${ }^{151}$ While both the United States and Japan are not members, the fact that many nations have embraced the AIIB was not expected.

The United States and Japan were caught off guard when a total of 57 countries, including Group of Seven members Britain, Germany and France jumped on board the АII B bandwagon by March. ${ }^{152}$

The new bank "is seen as encroaching on the regional financial clout of Tokyo and its ally Washington." 153 Not surprisingly, Japan is attempting to strengthen its ties to other Asian nations as a counter-balance to the new Chinese led bank. ${ }^{154}$

China's spearheading the new bank manifests China's ambition to take a seat at the table of international law governance architects. China will be empowered to leverage the АІІв to extract strategic benefits as the United

149 Surya P. Subedi, Are the Principles of Human Rights "Western" Ideas? An Analysis of the Claim of the "Asian" Concept of Human Rights from the Perspectives of Hinduism, 30 CAL. W. INT'L L.J. 45 (1999), p.62.

150 Michael Schuman, Whose Money Will the World Follow? (2015), http://www.bloomberg .com/news/articles/2015-05-14/u-s-china-rivalry-whose-money-will-the-world-follow-. Last visit: September 12, 2017.

151 See S.R. Why China Is Creating A New “World Bank” for Asia (2014), http://www.economist .com/blogs/economist-explains/2014/11/economist-explains-6. Last visit: May 11, 2016.

$15^{2}$ See Leika Kihara and Linda Sieg,Japan Unveils \$no Billion Plan to Fund Asia Infrastructure, Eye on AIIB, (2015), http://www.reuters.com/article/2015/05/21/us-japan-asia-investmentidUSKBNoO617G20150521. Last visit: September 12, 2017.

153 New \$1oo Bn BRICS Bank Opens in China to Challenge US-led Lenders (2015). http://news .yahoo.com/brics-bank-opens-business-xinhua-015809429.html. Last visit: May 11, 2016.

154 See Masaaki IwamotoKyoko Shimodoi (2015). http://www.bloomberg.com/news/articles/ 2015-05-21/japan-boosts-asia-infrastructure-outlays-as-china-champions-aiib. Last visit: May 11, 2016. See also Leika Kihara and Linda Sieg, Japan Unveils \$11o Billion Plan to Fund Asia Infrastructure, Eye on AIIB, (2015), http://www.reuters.com/article/2015/05/21/usjapan-asia-investment-idUSKBNoO617 G20150521. Last visit: September 12, 2017. 
States did with the existing infrastructure banks. Strategic undertones exist in the AIIB and "[a]lthough China tends to impose fewer conditions for development assistance, it still has a clear political agenda in its lending, though perhaps not as transparent as its Western counterparts. ${ }^{155}$ China has utilized its leverage by rejecting Taiwan's request to join the AIıв..$^{156}$

\subsection{China's OBOR}

China's One Belt One Road (“OBOR"), is a trillion dollar grand strategy ${ }^{157}$ envisioning a massive new network of inter-connected railways, roads, sea and airports throughout Asia, the Gulf Cooperation Council ("GCC"), Africa and into Europe, substantially influencing the global economy. ${ }^{158}$ овов forms an integral part of China's aspirational ascendancy both in Asia and in the global context ${ }^{159}$ and "will be a catalyst for shifting power alliances and the changing fortunes of nation states."160

In terms of scale or scope, овов has no parallel in modern history. It is more than 12 times the size of the Marshall Plan, America's post-World War II initiative to aid the reconstruction of Western Europe's devastated economies. Even if China cannot implement its entire plan, овов will have a significant and lasting impact. ${ }^{161}$

155 See Simon Chesterman, Asia's Ambivalence about International Law and Institutions: Past, Present and Futures, 27 EJIL 945 (2017), p. 976 (emphasis added).

156 Michael Schuman, Whose Money Will the World Follow? (2015), http://www.bloomberg .com/news/articles/2015-05-14/u-s-china-rivalry-whose-money-will-the-world-follow-. Last visit: September 12, 2017.

157 See Our Bulldozers, Our Rules, The Economist (2 July 2016). Describing овов as a means "of extending China's commercial tentacles and soft power".

158 See Charlie Campbell, China Says It's Building the New Silk Road. Here Are Five Things to Know Ahead of a Key Summit, Time (12 May 2017).

159 President Xi Jinping Delivers Important Speech and Proposes to Build a Silk Road Economic Belt with Central Asian Countries (PRC Ministry of Foreign Affairs, 7 September 2013) http://www.fmprc.gov.cn/mfa_eng/topics_665678/xjpfwzysiesgjtfhshzzfh_665686/ t1076334.shtml Last visit: September 12, 2017., noting овов's critical importance to China.

16o Alex Capri, China's Growing Influence On Middle East Shouldn't Be Lost On An Impulsive Trump Administration, Forbes (2017). https://www.forbes.com/sites/alexcapri/2017/o6/21/ china-obor-qatar-middle-east-america/\#469aod4a70e8. Last visit: September 12, 2017.

161 Brahma Chellaney, China's Imperial Overreach, Project Syndicate (2017), https://www .project-syndicate.org/commentary/one-belt-one-road-china-imperialism-by-brahmachellaney-2017-05?referrer=/TBsa5FyEfB. Last visit: September 12, 2017. 
ово R is composed of two principle venues: construction of new road, highways, bridges and overland infrastructure and the building of maritime facilities. ${ }^{162}$ China plans to build "a vast network of railways, energy pipelines, highways, and streamlined border crossings, both westward — through the mountainous former Soviet republics - and southward, toward Pakistan, India, and the rest of Southeast Asia."163 овов constitutes an important component of China's long-term strategic plan to regain dominance in Asia and prestige in the world 164 and as principle architect and leader, China stands to gain immensely by dominating crucial trade links. ${ }^{165}$ овов also will strengthen the continued internationalization of the Yuan the ramifications of which are discussed below. ${ }^{166}$

\subsection{The Yuan's Challenge to the U.s. Dollar's Reign \\ 2.3.1 Why Reserve Status Matters}

The status as global reserve currency is not merely a prestigious talking point; a nation whose currency is the world's reserve currency reaps substantial benefits: "reserve status permits discounted borrowing of loans. And, central banks of other countries must hold [the reserve currency] in reserve to facilitate trade, in turn appreciating the [reserve currency].... aid[ing] the reserve country with running a trade deficit in perpetuity."167

The dollar's role as the world's primary reserve currency helps all of us Americans by keeping interest rates low. Foreign countries buy United

162 James McBride, Building the New Silk Road (2015), http://www.cfr.org/asia-and-pacific/ building-new-silk-road/p36573. Last visit: September 12, 2017.

163 Id.

164 John Kemp, China's Silk Road challenges U.S. dominance in Asia (2014), http://www .japantoday.com/category/opinions/view/chinas-silk-road-challenges-u-s-dominancein-asia. Last visit: September 12, 2017.

165 See Isabel Reynolds, Abe Pitches Japan's Infrastructure on China's Silk-Road Patch (2015), http://www.bloomberg.com/news/articles/2015-10-22/abe-pitches-japan-sinfrastructure-on-china-s-silk-road-patch. Last visit: September 12, 2017.

166 See Xi Jinping's 'One Belt, One Road' Strategy Is Showing the Way To A New World Order, http://www.scmp.com/comment/insight-opinion/article/2054143/xi-jinpings-onebelt-one-road-strategy-showing-way-new-world?utm_source=\&utm_medium=\&utm _ campaign=SCMPSocialNewsfeed. Last visit: September 12, 2017.

167 Jordan Totten, BRICS New Development Bank Threatens Hegemony Of U.S. Dollar (2014). http://www.forbes.com/sites/realspin/2014/12/22/brics-new-development-bankthreatens-hegemony-of-u-s-dollar/. Last visit: September 12, 2017. 
States Treasury debt not just as an investment, but because dollardenominated assets are the best way to hold foreign exchange reserves. ${ }^{168}$

If the us Dollar loses its luster as the premier reserve currency the us will suffer and would constitute a serious challenge to the United States' economy severely constraining U.S. policy makers.

Nations whose money does not enjoy the status of reserve currency cannot create staggering amounts of new currency without shouldering increased risk of inflationary currency debasement. If the dollar were no longer the world's reserve currency, the U.s. would be forced to assume similar risk, severely constraining the flexibility of American policy makers. ${ }^{169}$

This distinctive status of the Dollar is the objective of international envy ${ }^{170}$ and U.S. rivals have raised the specter of replacing the Dollar since reserve status is inextricably linked to international political standing. For example, the fact that the energy rich nations of the Middle East and Persian Gulf nations price their oil and gas in USD boosts the dollar's importance and is a significant lever of strategic power for the U.s.

The petro-dollar system is the heart and soul of America's domination over the global reserve currency, and their right to make all nations have to purchase U.s. dollars to be able to buy oil in the open market. Bound through an agreement with Saudi Arabia and OPEC in 1973, this de facto standard has lasted for over 41 years and has been the driving force behind America's economic, political, and military power. ${ }^{171}$

168 Bill Conerly Future Of The Dollar As World Reserve Currency (2013) http://www .forbes.com/sites/billconerly/2013/10/25/future-of-the-dollar-as-world-reservecurrency/\#ef794f61517a. Last visit: September 12, 2017.

169 Joel Slawotsky, Sovereign Wealth Funds as Emerging Financial Superstars: How U.S. Regulators Should Respond, 40 Geo. J. Int'l L. (2009), p. 1239.

170 http://www.telegraph.co.uk/finance/comment/liamhalligan/10978178/The-dollars-70year-dominance-is-coming-to-an-end.html. Last visit: September 12, 2017.

171 China Signs Currency Swap Deal With Qatar in The Heart of Petro-Dollar System (2014). http://www.examiner.com/article/china-signs-currency-swap-deal-with-qatar-theheart-of-petro-dollar-system. Last visit: September 12, 2017. 
The pricing of energy sales seals in Dollars has been a major boon to the United States. Yet this may also change over time.

While this new agreement between China and Qatar is only for the equivalent of $\$ 5.7$ billion over the next three years, Qatar becomes the 24th nation to open its Forex market to the Chinese currency, and solidifies acceptance of the Yuan as a viable option for the future in the Middle East. ${ }^{172}$

Traditional opponents of U.s. hegemony have recognized the unique status of the Dollar. Both former Venezuelan President Chavez and former Iranian President Ahmadinejad had called for the world to stop using the United States Dollar as a means of payment, and anticipated the day the Dollar is no longer the world's reserve currency. ${ }^{173}$ Chinese and Russian officials have made similar statements. ${ }^{174}$ "Spurred on by their often testy relations with the United States, Russia and China have long advocated reducing the role of the dollar in international trade."175

Russia and China intend to use their national currencies to settle more energy deals to guard against instability in a world energy market dominated by the us dollar, Russian President Vladimir Putin said..... ${ }^{176}$

172 China Signs Currency Swap Deal With Qatar in The Heart of Petro-Dollar System (2014). http://www.examiner.com/article/china-signs-currency-swap-deal-with-qatar-theheart-of-petro-dollar-system. Last visit: September 12, 2017.

173 See Iran President Calls U.S.Dollar 'Worthless', Assoc. Press (2007), http://www.msnbc .msn.com/id/21870271/. Last visit: May 11, 2016.

174 Andrew Batson, China Takes Aim at Dollar, wall. St. J. (2009), at A1, http:// online.wsj .com/article/SB123780272456212885.html (China). Last visit: May 11, 2016; Gleb Bryanski, China backs talks on dollar as reserve-Russian source, REUTERS (2009). http://www .reuters.com/article/usDollarRpt/idUSLJ93633020090319 (Russia). Last visit: September 12, 2017.

175 Putin Says China, Russia to Settle More Trade In Yuan. http://www.reuters.com/ article/2014/11/10/us-russia-economy-idUSKCNoIUoHV20141110 Nov 10, 2014. Last visit: September 12, 2017.

176 Li Xiang China, Russia to Use Yuan, Trouble In More Energy Deals, (2014). http://usa .chinadaily.com.cn/business/2014-11/11/content_18897132.htm. Last visit: September 12, 2017. 
For Russia, U.s. led Western sanctions in response to Russian military adventures in the Ukraine have created great incentive for Russia to squash the Dollar's status ${ }^{177}$ and strongly supports the Yuan's rising power. ${ }^{178}$

\subsubsection{The Yuan's Burgeoning Role as a Reserve Currency}

The strongest potential rival to the Dollar is the Chinese Yuan. ${ }^{179}$ China clearly has a major interest in promoting the Yuan since "[t]he No. 1 status of the greenback leaves China's wealth and economic health reliant on U.s. policya predicament Beijing desperately wishes to change."180

The signing of deals using the Yuan instead of the Dollar is increasing ${ }^{181}$ and Brazil, India and Russia are entering into non-Dollar deals.

Beijing has struck numerous agreements with Brazil and India that bypass the dollar. China and Russia have also set up rouble-yuan swaps pushing America's currency out of the picture.... Gazprom Neft, Russia's third-largest oil producer, is now settling all of its crude sales to China in renminbi, in the most clear sign yet that western sanctions have driven an increase in the use of the Chinese currency by Russian companies. ${ }^{182}$

177 Putin Says China, Russia to Settle More Trade In Yuan. http://www.reuters.com/ article/2014/11/10/us-russia-economy-idUSKCNoIUoHV20141110 Nov. 10, 2014. Last visit: September 12, 2017.

178 See Kenneth Rapoza, Russia's Sberbank Lending In Chinese Currency (2015). http:// www.forbes.com/sites/kenrapoza/2015/06/o7/russias-sberbank-lending-in-chinesecurrency/\#76e2341427da. Last visit: September 12, 2017.

179 The Ruble itself is currently not viewed as a viable alternative. See Chris Wright, A Plunging Ruble Shows Russia's Spiraling Decline (2014). http://www.forbes.com/sites/ chriswright/2014/11/07/a-plunging-rouble-shows-russias-spiralling-decline/. Last visit: September 12, 2017. See also Holly Ellyatt, Russia's Reserve Fund Could Run Empty in 2016 (2015). http://www.cnbc.com/2015/10/27/russias-reserve-fund-could-run-empty-in-2016. html Oct 27. Last visit: September 12, 2017.

180 Michael Schuman, Whose Money Will the World Follow? (2015), http://www.bloomberg .com/news/articles/2015-05-14/u-s-china-rivalry-whose-money-will-the-world-follow-. Last visit: September 12, 2017.

181 See also Jordan Totten, BRICS New Development Bank Threatens Hegemony Of U.S. Dollar (2014). Last visit: September 12, 2017. Dec 22, 2014 See also Chiara Albanese Russia Seals Deal With China on Currency Swap (2014) http://blogs.wsj.com/moneybeat/2014/10/13/ russia-moves-closer-to-china-with-currency-swap-deal/. Last visit: September 12, 2017.

182 See Jack Farchy, Gazprom Neft Sells Oil To China In Renminbi Rather Than Dollars (2015). https://next.ft.com/content/8e88d464-0870-11e5-85de-00144feabdco. Last visit: September 12, 2017. 
While the pro-Yuan users are expectedly the new architects as well as developing nations such as Indonesia, ${ }^{183}$ surprisingly many U.s. allies are also pursuing this venue. ${ }^{184}$ Canada has embraced the Yuan and has signed a deal that "will allow direct business between the Canadian dollar and the Chinese yuan, cutting out the middle man-in most cases, the U.S. dollar."185 In fact the deal makes "Canada the first country in the Americas to have a deal to trade in the renminbi." 186 The U.K. has also announced agreements to use the Yuan. ${ }^{187}$

Clearly the long-term prospect of diversification of energy sales being priced in Yuan would substantially enhance China's empowerment. Moreover, without the exclusive support of the IMF, World Bank and ADB, ${ }^{188}$ the powerful status of the USD is at risk of being re-set since" [t]he dollar's hegemony continues to be cemented, meanwhile, by the operations of the International Monetary Fund and World Bank."189 Furthermore, China's овоR also greatly increases Yuan internationalization. In sum, the Yuan is on track to become a major global currency conferring an enhanced status to China at the expense of the United States.

\section{$2.4 \quad$ BRICs Bank-NDB Bank}

The NDB is another alternative IFI, "envisioned as an answer to the current international financial system, which is dominated by the West"190 and should

183 Indonesia to Use Yuan in Trade With China From 2016 http://www.plenglish.com/index .php?option=com_content\&task=view\&id=4366281\&Itemid=1. Last visit: May 11, 2016.

184 See News Release-People's Bank of China swap line (2013) http://www.bankofengland .co.uk/publications/Pages/news/2013/033.aspx. Last visit: September 12, 2017.

185 Canada, China Sign Currency Deal Aimed At Boosting Trade (2014) http://www.cbc.ca/ news/politics/canada-china-sign-currency-deal-aimed-at-boosting-trade-1.2828707. Last visit: September 12, 2017.

186 Id. Last visit: September 12, 2017.

187 Katy Barnato, UK Pushes To Be 'China's Best Partner' Despite Fears (2015). http://www.cnbc .com/2015/09/21/uk-pushes-to-be-chinas-best-partner-despite-fears.html. Last visit: May 11, 2016.

188 http://www.telegraph.co.uk/finance/comment/liamhalligan/10978178/The-dollars-70year-dominance-is-coming-to-an-end.html. Last visit: September 12, 2017.

189 The IMF has already implicitly acknowledged that the Us dollar's unchallenged reign is ending. http://www.forbes.com/sites/kenrapoza/2016/07/21/canadas-dollar-beats-chinas -currency-in-world-trade-but-not-for-long/\#77d594d71692. Last visit: Setember 12, 2017.

190 Shannon Tiezzi, Don't Forget About the New BRICS Bank (2015) http://thediplomat .com/2015/07/dont-forget-about-the-new-brics-bank/. Last visit: September 12, 2017. 
be viewed in the context of the other new architectural initiatives. ${ }^{191}$ "Although the BRICs comprise over one-fifth of the global economy, together they wield about 11 percent of the votes at the IMF."192 In contrast to the Chinese dominated AIIB, the NDB is a project of several nations all seeking a viable substitute to the current global governance architecture and serves as an "important [] reminder that China is not alone in seeking alternatives to the Western financial system." ${ }^{193}$

The objective of the NDB is to embrace a new financial order, and "whatever diplomatic niceties are put on it, is intent on competing with the IMF and World Bank."194 This objective of offering an alternative is clearly stated on the bank's website:

The New Development Bank BRICS (NDB BRICS), formerly referred to as the BRICs Development Bank, is multilateral development bank operated by the BRICs states (Brazil, Russia, India, China and South Africa) as an alternative to the existing US-dominated World Bank and International Monetary Fund. ${ }^{195}$

Unlike the United States dominated IM F and World Bank the NDB's goal is to provide equal-share voting basis, with each of the five signatories contributing $\$ 10$ billion to the initial $\$ 5$ o billion capitalization ${ }^{196}$ intending to provide funding for infrastructure and "sustainable development" projects. ${ }^{197}$ The NDB bank is intended to reduce the influence of the United States led IMF and World Bank and has been enthusiastically embraced by Russia.

191 Malcolm Scott, Here's the \$17 Trillion Reason Why the BRICs Summit This Week Is a Big Deal (2015). http://www.bloomberg.com/news/articles/2015-07-06/here-s-the-17-trillionreason-why-the-brics-summit-this-week-is-a-big-deal. Last visit: September 12, 2017.

192 Raj M. Desai and James Raymond Vreeland What the new bank of BRICS is all about https://www.washingtonpost.com/news/monkey-cage/wp/2014/07/17/what-the-newbank-of-brics-is-all-about/. Last visit: September 12, 2017.

193 Shannon Tiezzi, Don't Forget About the New BRICS Bank (2015). http://thediplomat .com/2015/07/dont-forget-about-the-new-brics-bank/. Last visit: September 12, 2017.

194 http://www.telegraph.co.uk/finance/comment/liamhalligan/10978178/The-dollars-70year-dominance-is-coming-to-an-end.html. Last visit: September 12, 2017.

195 http://ndbbrics.org/. Last visit: September 12, 2017.

196 Raj M. Desai and James Raymond Vreeland, What The New Bank of BRICS Is All About https://www.washingtonpost.com/news/monkey-cage/wp/2014/07/17/what-the-newbank-of-brics-is-all-about/. Last visit: September 12, 2017.

197 Id. 
It makes sense that Russia would be the first to ratify the bank. The NDB now is in their political interest, perhaps more so than in Russia's economic interest. The country is currently viewed by the West as the biggest antagonist state around, with sanctions against Russia heading into a year starting next month. Since then, Russia's government has been touting non-dollar deals with China, a minor trading partner at the moment, and created a small non-euro customs union with Belarus, Armenia and Kazakhstan. ${ }^{198}$

In an early indication of using the NDB to advance political interests, Russia has given incentive to Greece to obtain funding in response to the EU-Greek crisis over Greece's debt. ${ }^{199}$ This would serve to bring Greece closer to Russia's sphere of influence ${ }^{200}$ and Russia is blunt that for Greece this is a "political decision."201

\subsection{Technology, AI and Space Exploration-Portents of Change}

While the United States is home to important tech giants such as Intel, Microsoft, Google, Facebook and Twitter, Chinese rivals are making global inroads into diluting the corporate technological leadership of the United States. ${ }^{202}$ Many Chinese tech companies are becoming major players ${ }^{203}$ and "China's leaders are also pushing for China to become not just the world's largest robot buyer, but a leading robot maker.... [Chinese companies] are developing a range of robots for

198 With Russian Official Said To Head New BRICS Bank, Will Dollars Get Dissed? (2015). http:// www.forbes.com/sites/kenrapoza/2015/02/20/russian-official-said-to-head-new-bricsbank/. Last visit: September 12, 2017.

199 See Seema Mody, Russia May Win Politically If A Greek Deal Falls Through (2015). http:// www.cnbc.com/2015/07/13/russia-may-win-politically-if-a-greek-deal-falls-through.html. Last visit: September 12, 2017.

200 Pavel K. Baev Greece's Russian Fantasy; Russia's European Delusion (2015). http://www .brookings.edu/blogs/order-from-chaos/posts/2015/07/o8-greeces-russian-inspirationbaev. Last visit: September 12, 2017.

201 Sounak Mukhopadhyay, Greece Can Easily Get Funding From BRICS Bank: Russia (2015). http://www.ibtimes.com/greece-can-easily-get-funding-brics-bank-russia-1998515. Last visit: September 12, 2017.

202 Christina Larson, The Humbling of American Tech Giants in China (2016). http://www .bloomberg.com/news/articles/2016-08-02/the-humbling-of-american-tech-giantsin-china. Last visit: September 12, 2017; Kevin Sneaser and Jonathan Woetzel, China's Impending Robot Revolution (2016). http://www.wsj.com/articles/chinas-impendingrobot-revolution-1470241843. Last visit: September 12, 2017.

203 Jethro Mullen, Meet China's Tech Behemoths (2016). http://money.cnn.com/2016/05/17/ technology/china-tech-ehemoths/. Last visit: September 12, 2017. 
use in factories, and [] now the world's largest consumer-drone maker by dollar sales." ${ }^{204}$ Western technology is at risk of losing customers to China.

The joint push to limit alleged Western dominance in the digital sphere is not limited to regulation. In hardware, many Russian customers are switching from CISCO solutions to ZTE and Huawei technologies. ${ }^{205}$

In the crucial upcoming technological frontiers, the realms of artificial intelligence and space exploration, United States dominance is at risk. In the most vital technological spheres of the coming decades, robotics, space exploration and artificial intelligence, Chinese aspirational hegemony is self-evident. ${ }^{206}$

[China] laid out a development plan [] to become the world leader in A.I. by 2030, aiming to surpass its rivals technologically and build a domestic industry worth almost $\$ 150$ billion. Released by the State Council, the policy is a statement of intent from the top rungs of China's government: The world's second-largest economy will be investing heavily to ensure its companies, government and military leap to the front of the pack in a technology many think will one day form the basis of computing. ${ }^{207}$

A Chinese White Paper envisions China as the most powerful space nation ${ }^{208}$ and China is indeed on course to achieve a relative parity or perhaps superiority

204 Kevin Sneaser and Jonathan Woetzel, China's Impending Robot Revolution (2016). http://www.wsj.com/articles/chinas-impending-robot-revolution-1470241843. Last visit: September 12, 2017.

205 Alexander Gabuev, How China and Russia See The Internet (2015). https://www.weforum .org/agenda/2015/12/how-china-and-russia-see-the-internet/. Last visit: September 12, 2017.

206 NASA concedes China is a serious contender for leadership in space and Chinese ambitions are to use space exploration to stir innovation and achievement, https://www .bloomberg.com/graphics/2016-asia-space-race/china.html. Last visit: September 12, 2017. Another potential new architect, India is also rapidly expanding its technological prowess. http://timesofindia.indiatimes.com/india/indias-record-satellite-launch-ramps-upspace-race-chinese-media/articleshow/57248903.cms. Last visit: September 12, 2017. Aside from military empowerment China is also focusing on education and investing substantial resources http://www.nytimes.com/2013/01/17/business/chinas-ambitiousgoal-for-boom-in-college-graduates.html. Last visit: September 12, 2017. In an attempt to rival Western institutions https://www.theguardian.com/education/2010/feb/02/chineseuniversities-will-rival-oxbridge. Last visit: September 12, 2017.

207 See Paul Mazur, Beijing Wants A.I. to Be Made in China by 2030 (2017). https://www.nytimes .com/2017/07/20/business/china-artificial-intelligence.html. Last visit: September 12, 2017.

208 See http://www.spaceref.com/news/viewsr.html?pid=49722. Last visit: September 12, 2017. 
to the United States exploration. ${ }^{209}$ NASA concedes China is a serious contender for global leadership in space. ${ }^{210}$

Moreover, United States dominance in the internet has raised the selfinterests of both China and Russia in developing an alternative internet and accompanying technology ${ }^{211}$ to challenge the U.s. dominance as "[b]oth Russia and China share a concern over the Us domination of the internet."212 China and Russia led an effort to create a new international code of conduct submitting a proposal to the UN General Assembly ${ }^{213}$ in which internet traffic would be routed through an alternative architecture. ${ }^{214}$ These actions are designed to create an alternative to the us dominated internet and bring other nations within the new system. ${ }^{215}$

[China's] government is pushing to rewrite the rules of the global Internet, aiming to draw the world's largest group of Internet users away from an interconnected global commons and to increasingly run parts of the Internet on China's terms. It envisions a future in which governments patrol online discourse like border-control agents, rather than let the U.s., long the world's digital leader, dictate the rules. ${ }^{216}$

209 See http://nationalinterest.org/blog/the-buzz/parity-beginning-emerge-betweenamerica-china-space-16844. Last visit: September 12, 2017.

210 See https://www.bloomberg.com/graphics/2016-asia-space-race/china.html. Last visit: September 12, 2017. Another potential new architect, India is also rapidly expanding its technological prowess. See http://timesofindia.indiatimes.com/india/indias-recordsatellite-launch-ramps-up-space-race-chinese-media/articleshow/57248903.cms. Last visit: September 12, 2017.

211 http://www.wicwuzhen.cn/system/2015/07/17/020744492.shtml. Last visit: May 11, 2016.

212 China And Russia: The World's New Superpower Axis? http://www.theguardian.com/ world/2015/jul/o7/china-russia-superpower-axis. Last visit: September 12, 2017.

213 https://ccdcoe.org/sites/default/files/documents/UN-150113-CodeOfConduct.pdf. Last visit: September 12, 2017.

214 Cory Bennett,China, RussiaSeeking TheirOwnInternet, Warns FormerIntelChairman(2015). http://thehill.com/policy/cybersecurity/241759-china-russia-cyber-pact-threatensinternet-says-former-house-intel-chair. Last visit: September 12, 2017.

215 CoryBennett,China, RussiaSeeking TheirOwnInternet, WarnsFormerIntelChairman(2015). http://thehill.com/policy/cybersecurity/241759-china-russia-cyber-pact-threatensinternet-says-former-house-intel-chair. Last visit: September 12, 2017.

216 James T. Areddy, China Pushes to Rewrite Rules of Global Internet (2015). http://www.wsj .com/articles/china-pushes-to-rewrite-rules-of-global-internet-1438112980. Last visit: September 12, 2017. 
Significantly, from an economic standpoint, an alternative internet may very well lead to a change of control with respect to commerce:

'It is something [Russia and China] will be able to control' ... Traffic to these countries 'doesn't have to go through the World Wide Web anymore. It goes through this system, which has been set up mainly by China.'217

In addition to economic ramifications, an alternative internet will also have characteristics that are contradictory to Western style freedoms. ${ }^{218}$ "Both [China and Russia] are also tightening domestic control over digital data and have essentially axed formal cybersecurity relations with the United States."219 The cooperation includes an agreement to "jointly develop technology that protects their "socio-economic atmosphere," including campaigns to thwart technologies that might "disturb public order" or "interfere with affairs of the state,"220 These initiatives run contrary to current notions of freedom. "As the U.S. and Europe have started to press for United Nations norms guaranteeing Internet freedom, Russia and China have led a movement in the opposite direction."221

China and Russia have also agreed not to hack each other. "And while an unprecedented pact not to deploy network hackers against each other may prove largely symbolic, it's yet another glaring sign of the two countries' shared desire to shake up a world order largely dominated by the U.S. since the end of World War II." 222 This also may be a harbinger of conflict as nations may seek to use technology as a weapon ${ }^{223}$ and can also use it to enforce domestic control. ${ }^{224}$

\footnotetext{
217 Id.

218 Id.

219 Id.

220 Id.

221 Id.

222 Tom Risen, China, Russia Seek New Internet World Order (2015). http://www.usnews .com/news/articles/2015/05/14/china-russia-seek-new-internet-world-order. Last visit: September 12, 2017.

223 Douglas Rushkoff, Russia, The Internet And A New Way to Wage War? (2015). http://edition .cnn.com/2015/10/28/opinions/rushkoff-internet-cables-russia/. Last visit: May 11, 2016.

224 Xi Defends China's Great Firewall in Push for 'Cybersovereignty' (2015). http://www .bloomberg.com/news/articles/2015-12-16/china-s-xi-defends-web-controls-in-call-forcybersovereignty-. Last visit: September 12, 2017.
} 
The VPN crackdown and the pursuit of a narrow "cyber sovereignty" reveal much that is worrying about Beijing's vision for an illiberal global order. The free flow of information, whether it be economic, political or scientific in nature, has been an essential underpinning of global prosperity in recent decades. ${ }^{225}$

The next section will describe some of the potential new architects and will highlight their contrasting notions of norms. These differences in outlook stem from the differing historical, political, religious and cultural contexts than found in the nations of the present architects.

Irrespective of whether the ICJ or Restatement terminology is invoked, the nations that have been considered "uncivilized' and "non-advanced" are now holding admission tickets to the club of international law players. Whether from an economic ${ }^{226}$ or population perspective, ${ }^{227}$ the rising powers, will become important centers of influence.

The center of gravity for the world's population continues to shift from the developed world to the developing world. The highest growth in population is likely to occur in Africa, while the populations of most countries in South Asia and the Middle East are expected to continue rising,

225 The Dangers In Beijing's Bid for Cyber Sovereignty (2017). https://www.ft.com/content/ 52d588oc-7607-11e7-aze8-60495fe6ca71. Last visit: September 12, 2017.

226 China enjoys the world's second largest economy and India is considered the fourth largest and closing in on number three ranked Japan. See Joel Slawotsky, The Virtues of Shareholder Value Driven Activism: Avoiding Governance Pitfalls, 12 Hastings Business Law Journal, 521 (2016), p. 555. (“However, Japan's performance has been so lackluster that it has fallen behind China, and is now the world's number three economy. Japan is perilously close to slipping to the fourth position and being replaced by India. By some measures India has already taken the number three position from Japan.").

227 The combined populations of India and China represent approximately $40 \%$ of the world total of roughly 7.5 Billion, http://www.worldometers.info/world-population/. China has a population of 1.4 Billion. http://www.livepopulation.com/country/china.html. And India 1.3 Billion http://www.livepopulation.com/country/india.html. For a total of 2.7 billion people. Last visit: September 12, 2017. 
with India surpassing China as early as 2022 as the most populous nation on Earth. ${ }^{228}$

The historical, cultural, religious and political experiences of some of these rising states translate into legal norms and understandings that are substantially different from Western notions. The next sub-sections briefly describes several of these rising nations and contrasts their notions of rights with the current perspective.

\subsection{Brazil}

Brazil is an example of a "BRIC" nation and a rising power that "has more embassies in Africa than does the United Kingdom"229 and is projected to be the 6th largest economy in the next 15 years. ${ }^{230}$ However, Brazil's enforcement of Western based international norms and democratic principles is lackluster. ${ }^{231}$

The 2016 Rio Olympics highlighted serious human rights abuses (in the context of Western values) such as state sponsored police executions, torture as well as prison abuse. ${ }^{232} \mathrm{~A}$ host of "lesser" human rights abuses including police brutality and child abuse related to the Olympics have been well documented. ${ }^{233}$ Human rights organizations have chronicled extra judicial executions, prison torture, juvenile criminal system abuse and violence against protesters in Brazil. ${ }^{234}$ In addition, the media is under severe restrictions and

228 Defense Technical Information Center (DTIC), p.10. http://www.dtic.mil/doctrine/ concepts/joe/joe_2035_july16.pdf.]. Last visit: September 12, 2017.

229 Raj M. Desai and James Raymond Vreeland, What The New Bank of BRICS Is All About. https://www.washingtonpost.com/news/monkey-cage/wp/2014/07/17/what-the-newbank-of-brics-is-all-about/. Last visit: September 12, 2017.

230 http://www.bloomberg.com/news/articles/2015-04-10/the-world-s-20-largest-economiesin-2030. Last visit: September 12, 2017.

231 http://www.hrw.org/world-report/2014/country-chapters/brazil. Last visit: September 12, 2017 .

232 See Olympic Games 2016: How Rio Missed the Gold Medal for Human Rrights. https://www .theguardian.com/sport/2016/aug/o2/olympic-games-2016-rio-human-rights (noting over 20,000 families were forced to evacuate the Olympics area, sqalid conditions and that since 2009 there have been more "more than 2,6oo police killings in Rio."). Last visit: September 12, 2017.

233 See Rio Olympics Linked to Widespread Human Rights Violations, report reveals http:// www.theguardian.com/world/2015/dec/o8/rio-olympics-2016-human-rights-violationsreport. Last visit: September 12, 2017.

234 https://www.amnesty.org/en/countries/americas/brazil/report-brazil/. Last visit: September 12, 2017 . 
journalists risk arbitrary arrest for coverage of political protest. ${ }^{235}$ State sponsored torture has been singled out as a consistent and pervasive problem. ${ }^{236}$

\subsection{China}

The "spiritual progenitor" of the new architects, Chinese notions of democracy and individual rights vary significantly from Western norms. For example, in contrast to conferring rights onto individuals, "in Chinese Confucianism 'rights' are placed strongly on the idea of collective or group rights and manifest themselves individually only in the form ovf duties that an individual has to the group. In this sense, in Confucianism there are no rights that are individual in nature."237

China employs one of the world's most exhaustive Internet censorship regimes to suppress dissidence and other information that affects "national security". It uses technology to enforce censorship and discipline political opponents ${ }^{238}$ which in the eyes of the West limits freedom. Social-media postings can be deleted and search terms blocked, and websites including Facebook and Google have withdrawn from the country or have been barred from operating. ${ }^{239}$

China's crackdown on VPNs - which allow people to access and communicate with the outside world - is a clear demonstration of its attitudes towards the relationship between the free flow of information and national security.

235 http://www.hrw.org/world-report/2014/country-chapters/brazil Last visit: May 11, 2016.

236 Id. ("Torture is a chronic problem in police stations and detention centers. The United Nations Subcommittee on the Prevention of Torture and other Cruel, Inhuman or Degrading Treatment reported that it received "repeated and consistent" accounts from inmates of beatings and other allegations of ill-treatment during police custody.").

237 Weatherly, R. The Discourse of Human Rights in China, Macmillan Press, London (1999). p. 46.

238 See Xi Defends China's Great Firewall in Push for 'Cybersovereignty' (2015). http://www .bloomberg.com/news/articles/2015-12-16/china-s-xi-defends-web-controls-in-call-forcybersovereignty-. Last visit: May 11, 2016. See also http://www.nytimes.com/2016/04/o9/ world/asia/china-blocks-economist-time.html.Last visit: September 12, 2017; https://www .washingtonpost.com/world/asia_pacific/chinas-scary-lesson-to-the-world-censoringthe-internet-works/2016/05/23/413afe78-fff-11e5-8bb1-fi24a43f84dc_story.html; https:// qz.com/893238/china-is-cracking-down-on-vpns-making-it-harder-to-jump-the-greatfirewall/. Last visit: September 12, 2017. (discussing a "crackdown on virtual private networks", and the call "on Chinese telecommunications providers to "perform background investigations" on internet data centers, content delivery networks, and internet service providers to ensure that businesses using the internet use it for purposes relevant to their business." Last visit: September 12, 2017.

239 Id. (2015). http://www.bloomberg.com/news/articles/2015-12-16/china-s-xi-defends-webcontrols-in-call-for-cybersovereignty-. Last visit: September 12, 2017. 
Apple, the us tech company, was forced at the weekend to remove from its China App Store popular applications that enable users to bypass the "Great Firewall of China". 240

From the perspective of Western norms, there have been extensive reports about serious abuse of rights in China. ${ }^{241}$ A United Nations Committee has shown grave concern over China's record on torture. ${ }^{242}$ In 2016, the Permanent Court of Arbitration rejected, in the absence of China, most of Chinese historical claims in the South China Sea and ruled against artificial island building in the region. ${ }^{243}$

\subsection{India}

India is rapidly becoming an economic powerhouse and has emerged as the fourth largest — and by some measures the third biggest global economy ${ }^{244}$ making India an integral member of the BRICS.

India has been critiqued (based on the norms of conduct framed by the existing architects) for a variety of human rights abuses including: limitations on freedom of expression, discrimination, child labor and domestic violence such as honor killings. ${ }^{245}$ Children are forced to work rather than attend school and often work in dangerous and abusive conditions. ${ }^{246}$ Approximately half of young children are malnourished and thousands are trafficked and sold. ${ }^{247}$

240 The Dangers In Beijing's Bid for Cyber Sovereignty. September 12, 2017. https://www.ft.com/ content/52d588oc-7607-11e7-a3e8-60495fe6ca71 July 31, 2017. Last visit: September 12, 2017.

241 http://www.aljazeera.com/news/2015/o3/china-web-torture-critics-150319145251265. html. Last visit: May 11, 2016. ("Forcibly committing activists, who are subject to being shackled, tortured and given psychotropic drugs, is now being used as an alternative to the red reeducation camps.").

242 UN Torture Committee issues scathing indictment of China's record on torture (2008) http://www.tibetcustom.com/article.php/20081205000108283. Last visit: May 11, 2016.

243 https://pca-cpa.org/wp-content/uploads/sites/175/2016/o7/PH-CN-2016o712-PressRelease-No-11-English.pdf. Last visit: September 12, 2017. China rejected the Court's jurisdiction. https://www.theguardian.com/world/2016/jul/12/philippines-wins-southchina-sea-case-against-china. Last visit: September 12, 2017.

244 http://thediplomat.com/2014/05/world-bank-india-overtakes-japan-as-worlds-thirdlargest-economy/. Last visit: September 12, 2017

245 https://www.hrw.org/world-report/2017/country-chapters/india. Last visit: September 12, 2017.

246 Id.

247 Id. 
Honor killings are culturally accepted and Indian legal remedies to address "honor killings" is lackluster. ${ }^{248}$

[F]emale suspects in particular are disproportionately vulnerable to sexualized forms of extra-legal violence by state actors ... [the] Indian governments, both at the national and state levels, misapply statutory immunity provisions to shield security forces who commit violence against women. ${ }^{249}$

India provides an example of a nation that is modernizing and becoming a player yet has kept numerous cultural traditions and practices that are not in sync with Western norms of conduct.

\subsection{Russia}

While not an economic superpower, Russia is another example of a nation that has widely differing views on rights and is trying to obtain a seat as an architect of international law. Russia, successor to the USSR, has the world's largest stockpile of nuclear weapons.

Russia has been severely criticized — when evaluated by Western standardsby the United Nations with respect to state sponsored torture and cruel and degrading treatment. ${ }^{250}$ According to HRW, freedom of speech,, ${ }^{251}$ expression, arbitrary arrests, torture and various human rights abuses plague Russia.

In May 2013, the United Nations special rapporteurs for freedom of association, human rights defenders, and freedom of expression voiced serious concerns about the "obstructive, intimidating, and stigmatizing

248 Id.

249 See Surabhi Chopra, Dealing with Dangerous Women: Sexual Assault Under Cover of National Security Laws in India. 34 Boston Int'l Law Journal 319 (2016). pp. 322-323.

250 See Nick Cumming-Bruce (2012). http://www.nytimes.com/2012/11/24/world/europe/ un-panel-criticizes-russia-on-human-rights-treaty.html. Last visit: May 11, 2016. ("United Nations officials issued a scathing assessment of Russia's compliance with an international treaty against torture and cruel and degrading punishment, highlighting, among a number of "troubling trends," the increasing intimidation of people and organizations trying to monitor human rights.").

251 See Daniel Ortner, Conscientious Offenders: Russia's Ban on “Extremist” Religious Literature, And the European Court of Human Rights http://www.vjil.org/assets/pdfs/vol56/VJIL_56.1_ Ortner_FINAL.pdf. Last visit: September 12, 2017. 
effects" of waves of inspections of Russian NGOs in connection with the "foreign agents" law. ${ }^{252}$

"It is not the exception but the norm in Russia for police to torture and abuse detainees." 253 It is well documented that in Russian prisons, "[d]uring interrogation, detainees were forced to crawl on the ground and were beaten so severely that some sustained broken ribs and injuries to their kidneys, liver, testicles, and feet. Some were also tortured with electric shocks."254

Restrictions on expression are increasing 255 and freedoms of assembly and association are all under extreme limitation by the Russian government.

Growing numbers of individuals were arrested and criminally charged for criticizing state policy and publicly displaying or possessing materials deemed extremist or otherwise unlawful under vague national security legislation. ${ }^{256}$

Russia has endorsed China's crackdown on internet access and "passed a law banning software that allows users to view internet sites barred in the country anonymously. ${ }^{257}$

Russia has moved closer to the Chinese model of internet policing in recent years. In 2014, lawmakers approved legislation demanding that companies handling the private data of Russian citizens base their relevant servers inside Russia. This allows security forces to inspect and

252 http://www.hrw.org/world-report/2014/country-chapters/russia. Last visit: May 11, 2016.

253 Marc Bennets, Torture and Abuse by Police is the Norm in Russian Prisons (2016). http:// www.newsweek.com/2016/04/o8/russia-police-custody-torture-abuse-441489.html. Last visit: September 12, 2017.

254 https://www.hrw.org/reports/200o/russia_chechnya4/summary.htm Last visit: September 12, 2017 .

255 Daniel Ortner, Conscientious Offenders: Russia's Ban on "Extremist" Religious Literature, and the European Court of Human Rights, p. 150. http://www.vjil.org/assets/pdfs/vol56/ VJIL_56.1_Ortner_FINAL.pdf. Last visit: September 12, 2017. ("Indeed, as part of a recent surge of laws restricting religious freedom, freedom of speech, and the right of assembly in Russia, the country has actually strengthened its laws against 'extremism.").

256 https://www.amnesty.org/en/countries/europe-and-central-asia/russian-federation/ report-russian-federation/. Last visit: September 12, 2017.

257 See Ryan Browne, Russia Follows China in Tightening Internet Restrictions, Raising Fresh Censorship Concerns (2017). https://www.cnbc.com/2017/07/31/russia-follows-china-invpn-clampdown-raising-censorship-concerns.html. Last visit: September 12, 2017. 
raid server facilities and also gives Moscow a greater ability to censor unwanted content. ${ }^{258}$

Russia has been criticized for violating Western norms of conduct in neighboring Chechnya for which "the European Court of Human Rights (ECtHR) had issued over 200 judgments holding Russia responsible for grave human rights violations in Chechnya." 259 Russian military adventurism in Crimea ${ }^{260}$ and Syria $^{261}$ has also resulted in severe criticism over human rights violations. ${ }^{262}$ The majority of states in the UN General Assembly criticized Russia's annexation of the Crimean Peninsula as illegal under international law. ${ }^{263}$

\subsection{Saudi Arabia}

Another nation with rising influence and a potential shaper of international law is Saudi Arabia. Saudi Arabia enjoys an important role as the largest crude oil producer which has produced an incredible amount of cash-now a potential \$2 trillion dollar sovereign wealth fund ${ }^{264}$ which dwarfs the current largest SWF, Norway's. ${ }^{265}$ Moreover, Saudi has embarked on an economic moderniza-

258 Damen Shaekov, Vladmir Putin Defends China's Internet Censorship (2017). http://www .newsweek.com/putin-defends-chinas-internet-censorship-wont-follow-beijing-578973. Last visit: September 12, 2017.

259 http://www.hrw.org/world-report/2014/country-chapters/russia. Last visit: May 11, 2016.

26o See Gleb Stoly Yarov, Russia Annexed Crimea Which Borders Ukraine in 2014 Two Years After Annexation, Putin Seeks to Bind Crimea by Bridge to Russia.(2016). http://www.reuters. com/article/us-ukraine-crisis-russia-crimea-idUSKCNoWK2EA. Last visit: May 11, 2016. See also Russia Flexes Its Military Muscle In Crimea http://news.sky.com/story/russiaflexes-its-military-muscle-in-crimea-10164242. Last visit: September 12, 2017.

261 See Adam Entous and Gordon Lubold Russia Bombed Base in Syria Used by U.S. (2016). http://www.wsj.com/articles/russian-strikes-on-remote-syria-garrison-alarm-us-1469137231. Last visit: September 12, 2017. (noting Russian bombers attacked a base used by U.s. special forces).

262 https://www.amnesty.org/en/latest/news/2016/o2/russia-shameful-plan-to-deport-syrianrefugees-back-to-warzone-violates-international-law/. Last visit: September 12, 2017.

263 http://www.un.org/apps/news/story.asp?NewsID=47443. Last visit: September 12, 2017. See also https://www.unian.info/politics/1687011-un-general-assembly-votes-for-resolutionon-human-rights-in-crimea.html. Last visit: September 12, 2017.

264 http://www.bloomberg.com/news/articles/2016-05-25/key-questions-raised-by-the2-trillion-saudi-wealth-fund-plan. Last visit: September 12, 2017.

265 http://www.bloomberg.com/news/articles/2016-05-26/saudi-wealth-fund-plans-wouldmake-it-the-world-s-largest-chart. Last visit: September 12, 2017. 
tion program to develop its economy. ${ }^{266}$ Given the immense capital available, and modernization projects, Saudi is a potential rising power.

Saudi law and custom have very different understandings as compared to the Western world. For example, the right of women to vote and drive is not well settled ${ }^{267}$ and females are restricted to home without male consent or a male family member escort. 268

It is important for women coming to Saudi Arabia to know that women are not allowed to drive vehicles. In view of this fact, the University does provide daily transportation to and from the campus in University buses. Transportation is also provided for some of the evenings and on the weekends for shopping. ${ }^{269}$

Interestingly however, Saudi Arabia has recently moved somewhat towards a more Western model of gender equality with respect to women. In 2015, Saudi females were permitted to vote, although Saudi women had to be driven to the polling station ${ }^{270}$ as the ban on women driving remains strictly enforced. ${ }^{271}$

Another example of different notions of fairness and equality from existing Western norms include different understandings of rights.

In addition, various rights and freedoms Western citizens enjoy are limited or curtailed. The right to critique religion or government is not tolerated as in Western nations and can result in severe criminal punishment. "Saudi Arabia's Supreme Court [] upheld the sentence of blogger Raif Badawi: 1,0oo lashes and 10 years imprisonment. Badawi was arrested [] for cybercrime and "insulting Islam through electronic channels." 272

266 See http://vision2030.gov.sa/en. Last visit: September 12, 2017.

267 See, e.g., http://www.washingtonpost.com/blogs/worldviews/wp/2013/10/27/7-ridiculousrestrictions-on-womens-rights-around-the-world/ (noting restrictions on voting and driving. Last visit: September 12, 2017.

268 http://www.pmu.edu.sa/PDF/Viewer.aspx?ID=347. Last visit: September 12, 2017.

269 http://www.pmu.edu.sa/HR/Why_Working_at_PMU.aspx. Last visit: September 12, 2017.

270 Saudi Arabia's Women Vote in Election for First Time (2015). http://www.bbc.com/news/ world-middle-east-35075702. Last visit: September 12, 2017.

271 See http://www.reuters.com/article/saudi-driving-idUSLDE74NoET20110524. Last visit: September 12, 2017.

272 SeeAndrewV.Pestano,SaudiArabiaUpholds1o-yearPprison,1,oooLashingSentenceonBlogger http://www.upi.com/Top_News/World-News/2015/o6/o7/Saudi-Arabia-upholds-10 
The government severely restricted freedoms of expression, association and assembly, and cracked down on dissent, arresting and imprisoning critics, including human rights defenders ... Torture of detainees was reportedly common; courts convicted defendants on the basis of torturetainted "confessions" and sentenced others to flogging. Women faced discrimination in law and practice, and were inadequately protected against sexual and other violence despite a new law criminalizing domestic violence.... The authorities made extensive use of the death penalty and carried out dozens of public executions. ${ }^{273}$

Executions and beheadings have attracted much attention as the death penalty is imposed on a relatively frequent basis. ${ }^{274}$ Saudi Arabia has come under intensive criticism for the imposition of the "ultimate punishment" for nonserious crimes. ${ }^{275}$ Often, foreign nationals - ones without resources or Arabic language skills-are executed. ${ }^{276}$

The above section listed several nations that are considered rising powers and thus entering or on a path to entrance to the "club of advanced nations." International law will have to come to terms with potential international law sources that have radically different notions of rights and liberties than existing values, raising the specter of a radically different perspective to international law than the current notions of norms and principles.

4

\section{Ramifications and Challenges of the New Architects on International Law}

Norms and "rules only come into existence at particular historical periods under particular social conditions. They are in no way universal features of the human condition."277 It would be an historical anomaly for the new rising powers not to transform or substantially alter the existing governance architecture

-year-prison-100o-lashing-sentence-on-blogger/4651433688918/. Last visit: September 12, 2017.

273 https://www.amnesty.org/en/countries/middle-east-and-north-africa/saudi-arabia/. Last visit: September 12, 2017.

274 Id.

275 Id.

276 Id.

277 MacIntyre, A. After Virture: a Study of Moral Theory (1990), p. 67. 
to reflect the new power(s) interests. ${ }^{278}$ Accordingly, the international law writ will become increasingly shaped by nations once considered "developing" and/ or "less civilized." Moreover, the prospect of Western nations moving norms towards the new architects' exists. Economic and military power talks and "[s]tates may be particularly vulnerable to external pressure and thus tempted or even compelled to offer purely formal endorsements of international norms advocated by leading powers." 279

The new architects of the developing international financial and legal orders will:

no longer prepared to tolerate the interventionist attitude of the West, or accept the imposition of imprudent and perhaps harmful social and economic policies driven by Western countries, whether through direct or indirect means. ${ }^{280}$

Shifting notions of acceptable conduct is hardly surprising as international law does change over time. ${ }^{281}$ Accepted norms are subject to cyclical change depending upon shifting social and economic conditions thus allowing alternative notions of norms to emerge.

All major civilizations have for long periods treated a significant portion of the human race as "outsiders" not entitled to guarantees that could be taken for granted by "insiders." Few areas of the globe, for example, have never practiced and widely justified human bondage. All literate civilizations have for most of their histories assigned social roles, rights, and duties primarily on the basis of ascriptive characteristics such as birth, age, and gender. ${ }^{282}$

278 Simon Chesterman, Asia's Ambivalence about International Law: Past, Present and Futures (2016), https://academic.oup.com/ejil/article/27/4/945/2962207/Asia-s-Ambivalenceabout-International-Law-and. Last visit: September 12, 2017.

279 See Donnelly, The Relative Universality of Human Rights Jack Donnelly, Human Rights Quarterly, Volume 29, Number 2, (2007), p. 306. http://www.brandeis.edu/ethics/pdfs/ internationaljustice/biij/BIIJ2013/donnelly.pdf. Last visit: May 11, 2016.

280 Surya P. Subedi, Are the Principles of Human Rights "Western" Ideas? An Analysis of the Claim of the "Asian" Concept of Human Rights from the Perspectives of Hinduism, 30 CAL. W. INT'L L.J. 1999), p. 62.

281 See Filartiga, 630 F.2d, p. 881.

282 Donnelly, The Relative Universality of Human Rights Jack Donnelly, Human Rights Quarterly, Vol. 29 (2007), p. 291. http://www.brandeis.edu/ethics/pdfs/international justice/biij/BIIJ2013/donnelly.pdf. Last visit: September 12, 2017. 
Further corroborating the cyclical nature of international law, some argue that the current Western conceptualization of international law is itself a successor to a previous value system rather than constituting the true ideological progenitors of international law. Is international law really based on Western Christian civilization?

If the examination is limited to the nineteenth century and onwards, then the conclusion would be based on a rather narrow Euro-centric perception of international law. However, if the inquiry goes farther back in history, taking into account all evidence available in writing since the days of thriving ancient civilizations of other regions of the world, then the conclusion is a broader global one based on a universal outlook of the history of international law. ${ }^{283}$

This view claims that "modern international law" is a concept usurped from previous architects. ${ }^{284}$ However, "[t] he absence of sufficient literature unearthing and analyzing the practices of ancient States of Asia, Africa, and other parts of the world does not signify that human rights have their origin only in Christian Western civilization." ${ }^{285}$ International law may thus be viewed as a cyclical circle of architects, where dominant powers of centuries ago may reassert themselves depending upon new conditions. The following sub-sections identify several specific (and at times overlapping) areas where these potential clashes may occur.

\subsection{Core Issues Defining International Law}

4.1.1 The Vision of International Law

China and Russia envision a very different narrative of the international law writ. For example, in 2016, China and Russia issued a joint Declaration on the Promotion of International Law ${ }^{286}$ corroborating the titanic gap that remains after 70 years of the current international law paradigm. China and Russia critique "the practice of double standards or imposition by some States of their

283 Surya P. Subedi, Are the Principles of Human Rights "Western" Ideas? An Analysis of the Claim of the "Asian" Concept of Human Rights from the Perspectives of Hinduism, 30 CAL. W. INT'L L.J. (1999), p.58.

284 Id. p. 6 o.

285 Id. p. 49 .

286 http://www.mid.ru/en/foreign_policy/news/-/asset_publisher/cKNonkJEo2Bw/content/ id/2331698. Last visit: September 12, 2017. 
will on other States, and consider that imposition of unilateral coercive measures not based on international law, also known as 'unilateral sanctions', is an example of such practice." ${ }^{287}$ Moreover, crucially, the non-mention let alone de-emphasis on human rights and promotion of democratic notions of governmental legitimacy also demonstrates the irreconcilable vision of international law.

Illustrating the desire to recast the governance writ, China issued a White Paper on international law clearly attempting to attack the existing Western narrative. ${ }^{288}$ The position paper makes no mention of human rights or the rights of citizens. Instead emphasis is placed on sovereign equality, noninterference in others' internal affairs, and the non-use of force. China advances the argument that "international and regional rules should be discussed, formulated and observed by all countries concerned, rather than being dictated by any particular country. Rules of individual countries should not automatically become "international rules," still less should individual countries be allowed to violate the lawful rights and interests of others under the pretext of "rule of law."289 The latter statements are hardly surprising given Chinese allegations that the U.s. employs a double-standard. "[T] he self-proclaimed human rights defender has exposed its human rights 'myth' with its own deeds" 290

The emphasis on state sovereignty, non-intervention in the internal or external affairs of states, insistence on the UNSC as gatekeeper to authorize the use of military force and the criticism of extraterritorial application of domestic law (and the implicit critique of the United States) reflect this fundamentally different vision of international law.

\subsubsection{Western Notions of Human Rights}

Human rights advocacy has a distinctive Western slant since "at the time of the adoption of the UDHR, the UN and the General Assembly were dominated by Western States. As a result, the General Assembly passed many resolutions

\footnotetext{
287 Id.

288 See Chinese White Paper China's Policies on Asia-Pacific Security Cooperation (2017) http:// www.fmprc.gov.cn/mfa_eng/zxxx_662805/t1429771.shtml. Last visit: September 12, 2017.

289 Id.

290 See China Rails Against U.S. for Human Rights Violations (2017). http://www.reuters.com/ article/us-china-usa-rights-idUSKBN16G11N. Last visit: September 12, 2017. (noting China's claim that United States should not criticize China given gun violence, high incarceration levels, U.s. airstrikes against civilians and racial discrimination).
} 
during this time to suit the interests of Western States."291 The present understanding of human rights is the product of various initiatives inspired by and subject to the influence of Western international legal institutions dominated by the United States and its allies. ${ }^{292}$ Significantly for international law, several of the new architects have radically differing views on current norms particularly in the context of human rights. ${ }^{293}$ This is a serious issue because a "[g]rowing numbers of new international issues, ranging from migration, to global trade and finance, to access to pharmaceuticals are being framed as issues of human rights." 294

Are human rights "universal"? Under which lens should "international law" examine human rights conduct? In China, the discourse on human rights can be viewed in the context of "the group". 295 This is of course different from the individual based Western system. For example, in every Chinese Constitution, $\left(1954,1975,1978\right.$, and 1982) human rights are enumerated ${ }^{296}$ and pursuant to each Constitution, the rights of "society" or the "collective" trumps individual rights. ${ }^{297}$

The 1993 Bangkok Declaration, favored by many developing powers, reduces "universality" by reference to national and regional influences:

[W] hile human rights are universal in nature, they must be considered in the context of a dynamic and evolving process of international norm-setting, bearing in mind the significance of national and regional particularities and various historical, cultural and religious backgrounds. ${ }^{298}$

291 California Western, p. 61.

292 Karl Joseph Partsch, Human Rights in General, in Rudiger Wolfrum (ed.) United Nations Law: Politics and Practice, Martinus Nijoff Publishers, 1995, pp. 603-611.

293 Peter Baker and Ellen Barry, As Visit Ends, Obama Presses India on Human Rights and Climate Change (2015). http://www.nytimes.com/2015/01/28/world/asia/obama-endsvisit-with-challenge-to-india-on-climate-change.html?rref=collection\%2Ftimestopic \%2FChild\%2oLabor\&action=click\&contentCollection=timestopics\&region=stream\& module $=$ stream_unit\&version $=$ latest $\&$ contentPlacement $=2 \&$ pgtype $=$ collection. Last visit: September 12, 2017.

294 Donnely, The Relative Universality of Human Rights. p. 289.

295 Edward, R. Henkin, L. \& Nathan, A., Human Rights in Contemporary China, Columbia University Press, New York (1986).

296 Weatherly, R., The Discourse of Human Rights in China, (1999). p. 101.

297 Id. p. 103.

298 See Simon Chesterman, Asia's Ambivalence about International Law: Past, Present and Futures, (2016). https://academic.oup.com/ejil/article/27/4/945/2962207/Asia-sAmbivalence-about-International-Law-and. Last visit: September 12, 2017. 
Such language has moved towards the "mainstream" appearing in the 2005 World Summit Outcome Document and other contexts such as the 2012 ASEAN Human Rights Declaration (AHRD).

All human rights are universal, indivisible, interdependent and interrelated. All human rights and fundamental freedoms in this Declaration must be treated in a fair and equal manner, on the same footing and with the same emphasis. At the same time, the realisation of human rights must be considered in the regional and national context bearing in mind different political, economic, legal, social, cultural, historical and religious backgrounds. ${ }^{299}$

Some believe there is an inherently unsolvable conflict of values.

In the aftermath of the so-called "Islamic Revolution" in Iran in 1979, an Iranian delegate to the United Nations (UN) Human Rights Committee stated that international human-rights instruments, such as the 1948 Universal Declaration of Human Rights (UDHR) and the 1966 Covenants on Human Rights, contained provisions whose implementation would be contradictory in a country where Islamic law was observed. Another delegate from Iran stated to the Human Rights Committee that whenever divine law (i.e., Islamic law) conflicted with man-made law (i.e., human rights law), divine law would prevail.300

The eminent Harvard political scientist Samuel Huntington anticipated conflict between modern Western states and Confucian and Islamic nations. ${ }^{301}$ Huntington foresaw the "uncivilized" states modernizing and becoming militarily and economically powerful without accepting Western values and

299 Id.

300 Surya P. Subedi, Are the Principles of Human Rights "Western" Ideas? An Analysis of the Claim of the "Asian" Concept of Human Rights from the Perspectives of Hinduism, 30 CAL. W. INT’L L.J. (1999), p.46.

301 Huntington's essential anticipation was correct: a rising tension economically and militarily between the existing U.s. led order and nations which do not share these values. See https://www.foreignaffairs.com/articles/united-states/1993-06-01/clash-civilizations. Last visit: May 11, 2016. But see David Brooks, Huntington's Clash Revisited (2011). http:// www.nytimes.com/2011/03/04/opinion/o4brooks.html?_r=0. Last visit: September 12, 2017. (arguing that Huntington was wrong in claiming the populations of Arab nations were different and would not embrace democracy—as understood in the West—should there be an opportunity). 
norms. ${ }^{302}$ This prophetic narrative has been substantially accurate as the new architects have largely remained unaffected by Western criticisms $s^{303}$ and this fact has great implications for international law.

The first [upcoming challenge] is contested norms, in which increasingly powerful revisionist states and select non-state actors will use any and all elements of power to establish their own sets of rules in ways unfavorable to the United States and its interests. ${ }^{304}$

As detailed supra Part III, some of the new architects engage in a variety of conduct that presently constitutes human rights abuses pursuant to Western inspired norms and values including: denial of women's right to vote or to drive cars; state torture of prisoners; the legality or tacit encouragement of child labor and the acceptance of domestic violence and honor killings. With respect to labor rights, the rights of employees, including migrants and children, are not extensively recognized in the domestic legal systems of several new architects. ${ }^{305}$ It is, for example, acceptable in India for children to work although evidence exists of exploitation. ${ }^{306}$ International law will increasingly have a problem in terms of human rights recognitions which will need to be addressed. ${ }^{307}$

Moreover, the issue is not simply whether the modern Western concepts of human rights should be transplanted into the "newly civilized". The opposite is also true-certain rights currently entrenched in Western nations ${ }^{308}$ may in fact constitute egregious violations of cultural norms and be considered illegal,

302 Id.

303 See Part II I describing how various nations have sharply different versions of norms.

304 Defense Technical Information Center (DTIC), p. 4. http://www.dtic.mil/doctrine/ concepts/joe/joe_2035_july16.pdf. Last visit: September 12, 2017.

305 See David Barboza, In Chinese Factories, Lost Fingers and Low Pay (2008). http://www .nytimes.com/2008/01/05/business/worldbusiness/05sweatshop.html. Last visit: May 11, 2016. See Ending Child Labor in India (2015). http://www.nytimes.com/2015/06/27/ opinion/ending-child-labor-in-india.html. Last visit: September 12, 2017.

306 See Ending Child Labor in India (2015). http://www.nytimes.com/2015/o6/27/opinion/ ending-child-labor-in-india.html. Last visit: September 12, 2017.

307 http://www.bloomberg.com/news/articles/2016-04-26/prince-says-saudi-arabia-not-yetready-to-allow-women-to-drive. Last visit: May 11, 2016.

308 See Gay Marriage Around the World http://www.bbc.com/news/world-21321731. Last visit: May 11, 2016. See also US Supreme Court Rules Gay Marriage Is Legal Nationwide (2015) http://www.bbc.com/news/world-us-canada-33290341. Last visit: May 11, 2016. 
abhorrent and sacrilegious. ${ }^{309}$ Similarly, freedoms of speech, to assembly, to protest, to drive, or to worship, may be denied by the new architects based upon criteria that would be considered the most severe violations of human dignity the existing architects; $; 10$ but it is perfectly acceptable—or perhaps even obligatory — to deny these rights to certain groups based upon a religious, ethnic, gender or political basis. ${ }^{311}$

The new architects have objection to the Western push for human rights and perceive self-interest as the driver arguing that the West has cynically and exploitatively invoked human rights as a tool of hegemony. For example, the new architects perceive The Universal Declaration of Human Rights ("UDHR") as reflective of the interests of the existing architects. The UDHR focuses on individual rights and less on socio-economic rights - only 5 rights of a socioeconomic nature. The focus on individual rights inherently conflicts with Chinese notions of group rights and China has been in both ideological and economic conflict with the international community over rights in the past twenty years with many in the West claiming that China has done little to

309 See eg Russia Passes Anti-gay Law http://www.theguardian.com/world/2013/jun/30/ russia-passes-anti-gay-law; Lora Mofta, 'Gay Parties' Raided In Saudi Arabia; Religious Police Arrest Several People On Suspicion Of Homosexuality. http://www.ibtimes.com/gayparties-raided-saudi-arabia-religious-police-arrest-several-people-suspicion-1968038); Sadanand Dhume, The Politics of Gay Rights in India (2015). www.wsj.com/articles/thepoliticsl-of-gay-rights-in-india-143585489o. Last visit: September 12, 2017.

310 In the United States, using religious, ethnic, gender or racial criteria is strictly forbidden. See Due Process Clause, Equal Protection Clause, and Disenfranchising Felons (noting that discrimination based upon race, religion, gender or ethnic background violates the U.s. Constitution). See also Title VII of the Civil Rights Act, 1964 (prohibiting employers from discriminating against employees on the basis of color, race, sex, national origin or religion).

311 See U.S. State Department Report on Saudi Arabia, http://www.state.gov/documents/ organization/171744.pdf. Last visit: September 12, 2017. (Noting religious practice is strictly monitored and restricted); Amulya Gopalakrishnan, Housing: We Need A Law Against Discrimination (2015). http://timesofindia.indiatimes.com/home/sunday-times/all-thatmatters/Housing-We-need-a-law-against-discrimination/articleshow/47749962.cms. Last visit: September 12, 2017. (noting open discrimination in the Indian housing market); Lu-Hai Liang 'Discrimination Based on Ethnic Origin Can Be Blunt in China' (2015). http:// www.telegraph.co.uk/expat/expatlife/11500033/Discrimination-based-on-ethnic-origincan-be-blunt-in-China.html. Last visit: September 12, 2017. (noting widespread ethnic discrimination in China); Gray Tuttle, China's Race Problem, https://www.foreignaffairs .com/articles/china/2015-04-20/china-s-race-problem. Last visit: September 12, 2017 (noting ethnic and racial prejudice). 
improve its human rights record. ${ }^{312}$ New architects view the UDHR as a tool to utilize to further the existing architects interests' by vesting Western states with the moral high ground and authority to punish nations with different views. 313

Some have vigorously contested the Western contextual foundation of human rights; namely that such rights are universal.

Because the emergence and development of rights is tied up with the relationship of one class to another, and because rights are bestowed by the state and law, they simply cannot be universal, or equal for all classes. In a class society man cannot transcend national boundaries, but belongs to a certain class and a certain state. Whatever rights man has are class rights, they have distinctive class nature. ${ }^{314}$

In contrast to the UDHR, the United Nations Covenant on Economic, Social and Cultural Rights ("UNCESCR")—favored by the new architects—-formally acknowledges "the ideal of free human beings enjoying freedom from fear and want can only be achieved if conditions are created whereby everyone may enjoy his economic, social and cultural rights, as well as his civil and political rights and freedom". ${ }^{315}$ This conceptualization is more in sync with the historic Chinese views. ${ }^{316}$ "It is a simple truth that, for any country or nation, the right to subsistence is the most important of all human rights, without which the other rights are out of the question." 317

Opponents of the advancement of Western norms on developing nations can argue that not every nation will prosper under a Western inspired democracy and that some cultures require a vastly different value system or the society will be damaged. ${ }^{318}$ Interestingly, the 'Pew Global Attitudes Project' found that " 86 percent of Chinese said they were content with their country's direc-

312 Economy, E. \& Segal, A. 'China's Olympic Nightmare’ Foreign Affairs, July/August Vol. 87, No. 4 (2008). p. 5 o.

313 Weatherly, R., The Discourse of Human Rights in China (1999). p. 15.

314 Gu Chunde, 'Luelun Tianfu Renquan Shuo' (A Brief Discussion of Natural Rights Theory), Hongqi (Red Flag) (1982), pp. 34-35.

315 Ghandi, International Human Rights, Documents Blackstone Press Limited (1995), p. 375.

316 http://www.china.org.cn/e-white/7/7-I.htm par 1. Last visit: September 12, 2017.

317 China White Paper on Human Rights, p. 1. http://www.china.org.cn/e-white/7/7-I.htm. Last visit: September 12, 2017.

318 http://english.alarabiya.net/en/News/middle-east/2016/05/04/Sisi-says-Western-humanrights-values-don-t-apply-in-Egypt.html. Last visit: September 12, 2017. 
tion, double the percentage who said the same thing in 2002. In contrast, a mere 23 percent of Americans polled in the survey said they were satisfied with their country's direction. ${ }^{319}$ Apparently, Chinese citizens do not feel oppressed.

Should the West attempt to impose its vision of norms?

It was not about international relations, but rather an attempt to change other countries' domestic policies. On this issue, there are some important questions that need to be asked: Why should we try to make the rest of the world more like us? If we should try, in what specific ways should they be more like us? And finally, what is the best way to make others more like us? ${ }^{320}$

If the citizens of a nation are happy with their governance, should that model be copied or at a minimum respected as "working for its citizens"? Perhaps the West will look to embrace the norms of China out of enlightened self-interest?

4.1.3 Global Litigation Against Individuals and Businesses for Violations of International Law

Global litigation against individuals and businesses for international law violations will also be affected. ${ }^{321}$ In the United States, the Alien Tort Statute ("ATS") permits aliens to file suits against defendants for violations of international law. ${ }^{322}$ Pursuant to the ATs, only misconduct considered a violation of international law can be litigated and expectedly, defining international law through the lens of "civilized nations" is a significant issue in ATs litigation. ${ }^{323}$

319 French, Howard W. 'Despite Flaws, Rights in China Have expanded', New York Times August 2nd (2008).

320 See Simon Lester, Should the United States Use Treaties to Make the World "More Like Us"? p. 3. http://www.vjil.org/assets/pdfs/vjilonline4/Lester-v5-MLM_POST-PRODUCTION_ PUBLISH_ONLINE.pdf. Last visit: September 12, 2017.

321 See Andrew Sanger, Corrorations and Transnational Litigation: Comparing Kiobel With the Jurisprudence of English Courts https://www.asil.org/sites/default/files/AGORA/201401/ Sanger\%20AJIL\%2oUnbound\%20e-23\%20(2014).pdf. Last visit: May 11, 2016. (noting UK litigation against multinationals); See also Nevson v. https://www.biv.com/article/2016/10/ court-allows-eritrean-mine-workers-sue-nevsun/. Last visit: September 12, 2017.

32228 U.S.C. $\S 1350$ (2013).

323 For a discussion of the Alien Tort Statute - corporate liability and litigation, see Joel Slawotsky, Corporate Liability for Violating International Law Under The Alien Tort Statute: The Corporation Through the Lens of Globalization and Privatization Vol. 2013 2, p. 6. http:// www.qscience.com/doi/full/10.5339/irl.2013.6. Last visit: May 11, 2016. 
[W]e are persuaded that federal courts should not recognize private claims under federal common law for violations of any international law norm with less definite content and acceptance among civilized nations than the historical paradigms familiar when $\S 1350$ was enacted. ${ }^{324}$

Therefore, the misconduct is only actionable if considered a violation of international law through the lens of the "civilized nations". ${ }^{325}$ However, what if the benchmarks change as international law evolves? ${ }^{326}$ Ironically, modern ATs litigation which was greenlighted in Filartiga contains the inherent means of its own "reversal". In Filartiga, the court had to decide whether state sponsored torture was cognizable as a violation of international law. ${ }^{327}$ After examining the state of international law, the court found that state sponsored torture should now be considered as an accepted violation of customary international law because the majority of civilized nations held such conduct to be wrong. ${ }^{328}$ However, the rationale provides for the possibility that the opposite is also true; if the majority of civilized nations find torture acceptable — such conduct would not constitute an international law violation.

What happens when states that employ torture become international law architects? What would happen if a majority of the nations of the world found that discrimination against certain groups based upon ethnic, gender or religious criteria was not merely permissible but obligatory? Perhaps child labor is not abuse but educational or mandatory culturally to a majority of the nations?

We can all agree that actions should be in the "best interests of the child," but who decides what is in the "best interests of the child"? Opinions may vary. Could some of these provisions be interpreted in ways that conflict with U.s. policies? Probably. 329

324 See Sosa v. Alvarez-Machain, 542 U.s. 692, 731 (2004) (emphasis added).

325 Filartiga v. Pena-Irala 630 F.2d 876 (2d. Cir. 1980).

326 See Paul C. Szasz, General Law-Making Processes, in the United Nations and International Law 2, p. 31 (Chris C. Joyner ed., 1997) (noting customary international law is increasingly changing due to the "general acceleration of international interactions").

327 At the time of the ATs's enactment, torture was not one of the three violations of international law. The key is whether the "new" tort, here torture, could be defined with the same "definite content and acceptance among civilized nations than the historical paradigms familiar when $\S 1350$ was enacted." See Sosa v. Alvarez-Machain, 542 U.s. p. 731.

328 Filartiga, 630 F.2d p. 881 .

329 See Simon Lester, Should the United States Use Treaties to Make the World "More Like Us"? p. 5. http://www.vjil.org/assets/pdfs/vjilonline4/Lester-v5-MLM_POST-PRODUCTION_ PUBLISH_ONLINE.pdf. Last visit: September 12, 2017. 
Are honor killings a legitimate exception to the rule against extra judicial executions? Are public beheadings and executions torture or a method to prevent violent crime and moral decay? Moreover, U.s. courts have used the terminology majority of civilized nations (or the advanced nations), but is with respect to the populations or the number of states? If majority is a function of population, the two most populous nations are China and India whose combined populations dwarf the population of the United States and the EU and have very different norms. Regardless of whether majority is population based or not, the new architects will offer radically different views on a wide array of international law.

\subsubsection{The Global Discourse on CsR}

Similarly, the discourse on a host of CSR issues may be markedly affected as sustainability, environmental concerns, labor rights, climate change and the purpose of corporations are the subject of vastly different viewpoints largely depending upon self-interest.

Environmental crime ${ }^{330}$ — which has grown into an extensive industry worth between $\$ 91$ billion to $\$ 259$ billion a year-is a prime example. ${ }^{331}$

Environmental crime adversely impacts sustainability and development ${ }^{332}$ but different nations have different interests. "What may constitute a crime in one country, is not in another"333 and relatively few nations have taken substantial remedial enforcement and/or preventative action on environmental crime. ${ }^{334}$ In fact, several of the new potential architects are prominent actors in perpetrating, and/or aiders and abettors of, environmental crime. ${ }^{335}$

As the new architects rise in influence, their divergent interests and values will likely make international enforcement and agreements on environmental and sustainability more difficult. An example is climate change where rapidly

330 The Rise of Environmental Crime, http://unep.org/documents/itw/environmental_crimes .pdf. Last visit: May 11, 2016.

331 John Aglionby, Agencies Detect Sharp Increase In Environmental Crime, https://next .ft.com/content/ae6agafo-294a-11e6-8ba3-cdd781do2d89. Last visit: May 11, 2016.

332 The Rise of Environmental Crime, p. 4. http://unep.org/documents/itw/environmental_ crimes.pdf. Last visit: May 11, 2016.

333 The Rise of Environmental Crime, p. 25. http://unep.org/documents/itw/environmental_ crimes.pdf. Last visit: May 11, 2016.

334 John Aglionby, Agencies Detect Sharp Increase In Environmental Crime (2016). https://next .ft.com/content/ae6a9afo-294a-11e6-8ba3-cdd781do2d89. Last visit: September 12, 2017.

335 See generally The Report numerous references to Brazil, China and India. 
developing new architects may have vastly different self-interests than those of the existing architects. ${ }^{336}$ Similarly, the capacity of governments to enforce criminal law greatly varies. This is particularly true in many of the potential new architects, where very little development support has gone to strengthen the enforcement and judicial sector. ${ }^{337}$

In the $\mathrm{R}_{2} \mathrm{P}$ context, both China and India have expressed serious reservations.

Hegemonism, power politics and all forms of "new interventionism" pose a direct challenge to basic principles of international law including respect for sovereignty and territorial integrity and non-interference in other countries' internal affairs. ${ }^{338}$

India has also expressed deep hesitation on the $\mathrm{R}_{2} \mathrm{P}$ perhaps a reflection of "the contradiction between India's commitment to democracy internally and its stance on non-intervention internationally." ${ }^{339}$ While the new architects may have substantially different views on CSR, is it fair to impose Western standards? Are not the new architects responsible for protecting and promoting the interests of their citizens first? Do Western nations use CSR as a rationale to thwart the rise of the new architects? Is it the new architects that are responsible for Western notions trump the economic development of developing states by using CSR promotion as leverage?

\subsection{Rules Governing the Global Order}

U.s. dominance with respect to rule making is essential in accomplishing the goal of American exceptionality.

Leading — always — with the example of our values. That's what makes us exceptional. That's what keeps us strong. ${ }^{340}$

336 See Eduardo Porter, India Is Caught in a Climate Change Quandary (2015). http://www .nytimes.com/2015/11/11/business/economy/india-is-caught-in-a-climate-changequandary.html. Last visit: May 11, 2016 (noting the conflict between pro-growth in a developing nation and climate change advocacy).

337 The Rise of Environmental Crime, http://unep.org/documents/itw/environmental_ crimes.pdf. Last visit: May 11, 2016.

338 See Simon Chesterman, Asia's Ambivalence about International Law: Past, Present and Futures, (2016). https://academic.oup.com/ejil/article/27/4/945/2962207/Asia-sAmbivalence-about-International-Law-and. Last visit: September 12, 2017.

339 Id.

340 https://www.whitehouse.gov/the-press-office/2015/01/20/remarks-president-stateunion-address-january-20-2015. Last visit: May 11, 2016 (emphasis added). 
Unquestionably, the status of the United States as the indispensable nation is inextricably linked with the fact that global finance and trade is encapsulated in the rules and institutions dominated by the United States and has proximately caused "the spread of [United States] values, both in Asia and beyond". ${ }^{341}$ However, as the new architects rise, these rules and institutions will likely change reflecting the interests of the new powers.

\subsubsection{Financial Regulation and IF Is/International Organizations/sWFs}

In the virtual world of Disney, the character Jafar states the "Golden Rule" as "He who owns the gold makes the rules" ${ }^{342}$ However, with respect to the global governance architecture, the Golden Rule is: "He who makes the rules owns the gold". The architects of the global governance order reap the rewards. ${ }^{343}$ An important exemplar was the $\mathrm{SAP}^{344}$ program of the 1990s wherein loans were provided on terms obligating recipient nations to engage in substantial reform on an economic-political level and an encouragement of aligning with Western trade and foreign investment frameworks. ${ }^{345}$

SAPS contain a standard of globalization that demands that developing countries implement policy, legal, and institutional reforms consistent with those believed successful by the developed world. ${ }^{346}$

341 Rice, Condaleezza, 'The New American Realism Foreign Affairs, Vol 87 (2008). No. 4 p. 7 .

342 Quotes from Jafar (Character) from Aladdin (1992) www.imdb.com/character/choooo672/ quotes. Last visit: May 11, 2016.

343 See https://www.treasury.gov/press-center/press-releases/Pages/jl2630.aspx. Last visit: May 11, 2016 (noting financial sanctions imposed by the United States Treasury). The United States imposed economic sanctions on Russia based upon Russia's military intervention in Crimea which borders Ukraine. See http://www.state.gov/e/eb/tfs/spi/ ukrainerussia/. Last visit: May 11, 2016 (sanctions imposed over Ukraine). The sanctions, along with EU measures have damaged the Russian economy. See, e.g., Anna Andrianova Russian Outlook Dim Even If Sanctions End Early, World Bank Says (2016). http://www .bloomberg.com/news/articles/2016-04-06/russian-outlook-dim-even-if-sanctions-endearly-world-bank-says April 6. Last visit: September 12, 2017.

344 Structural adjustment program http://www.who.int/trade/glossary/storyo84/en/. Last visit: May 11, 2016.

345 http://www.globalissues.org/article/57/corporations-and-workers-rights. Last visit:May 11, 2016.

346 David P. Fidler, A Kinder, Gentler System or Capitulations? International Law, Structural Adjustment Policies, and the Standard of Liberal, Globalized Civilization, 35 Texas Journal International Law 387 (2000), p. 400. 
The existing IFIs are immensely powerful institutions whose power "is, by and large, controlled by the same group of "civilized" powers that were responsible for the creation of the multilateral system of capitulations-the European countries and the United States." 347 Thus, SAPs reflected a thinking among Western developed states-and enforced through the World Bank and the IMF - that developing nations failed to possess the internal makeup needed to engage in the global economy successfully. This belief actually is a manifestation of the superiority of civilized nations.

Emerging liberal thinking about the international legal order argues increasingly that it is possible to divide the world into zones, with a liberal zone of law, constituted by liberal states practising a higher degree of legal civilization, to which other states will be admitted only when they meet the requisite standards. This is in some respects a continuation of recurrent patterns in the history of Western legal thought, traceable, for example, in the sixteenth-century European divisions between Christians and infidels, or in James Lorimer's late-nineteenth century division of the world into a hierarchy of civilized nations, barbarous humanity, and savage humanity. ${ }^{348}$

In other words, the "civilized" world deemed the "uncivilized" as deserving of modernization (i.e. civilizing"). Thus, to deserve the benefits of Western "principles of sovereign equality and non-interference, they had to admit the inferiority of their cultures and permit massive interference with their internal affairs." ${ }^{349}$ The uncivilized have resented this approach and accuse the civilized of using the rationale of "the 'civilizing mission' justify the continuous intervention by the West in the affairs of Third World societies and provided the moral basis for the economic exploitation of the Third World that has been an essential part of colonialism." 350

Another aspect are the rules with respect to transparency, accountability and fairness, as such values are shaped and are a function of the existing

\footnotetext{
347 Id., p.403.

348 Benedict Kingsbury, Sovereignty and Inequality, in Inequality, Globalization, and World Politics 66, p. $9^{0 .}$

349 See David P. Fidler, A Kinder, Gentler System or Capitulations? International Law, Structural Adjustment Policies, and the Standard of Liberal, Globalized Civilization, 35 Texas Journal International Law 387 (2000), p. 396.

$35^{\circ}$ Anghie Chimni, Third World Approaches to International Law and Individual Responsibility in Internal Conflicts, Chinese Journal International Law 77, p. 85.
} 
Western IFIs and this self-advantage cannot be under estimated. ${ }^{351}$ There has been substantial interplay between SWFS and IFIS and the importance of IFIS vis a vis $\mathrm{SWFS}^{352}$ with respect to "the broad governance themes of climate change, corporate governance of portfolio companies, environmental protection, ethical investing, global financial regulation, human rights, regulation of SWFs, renewable energy and sustainable development." ${ }^{353}$ Not surprisingly, the United States has played a significant role and has influenced IFIs ${ }^{354}$ the World Bank and IMF have been involved in numerous less developed or "uncivilized nations." ${ }^{355}$ The manifestly clear conclusion is that institutions such as the World Bank and IMF possess substantial authority and the ability to substantially impact nations. While many nations liberalized their national economies (to varying degrees of practical success), ${ }^{356}$ there is no doubt that primarily, the civilized nations interests' were further advanced.

The regulation of swFs further illustrates the potential for change. During the OECD discussions with regard to regulating SWFs, the U.S. and EU nations established 'an informal group of member states' officials who meet in Washington, D.C. This system, driven by the United States and the EU, strives to draw up a code of best practice that includes a renunciation of political motives; however, it has stirred resentment among some countries with SWFs, particularly in China and some Gulf countries."357 Again, this corroborates the substantial influence wielded by architects and strongly suggests that the new architects will make rules that will serve the interests of the new architects.

351 Larry C. Backer, International Financial Institutions (IFIs) and Sovereign Wealth Funds $(S W F s)$ as instruments to combat corruption and enhance fiscal discipline in Developing States. pp. 3-4. http://www.qscience.com/doi/pdf/10.5339/irl.2015.swf.5http://www .qscience.com/doi/full/10.5339/irl.2015.swf.5. Last visit: May 11, 2016.

$35^{2}$ Id.

353 Id. pp. 4, 6-7.

354 Id. at note 23 ("That institutional architecture, the International Working Group of Sovereign Wealth Funds, "met at IMF Headquarters in Washington, D.C.").

355 Id. page 9 at note 60 ("It is important to remember in the discussion that follows that IFIs had been involved in sovereign investment for development and in the context of fiscal stabilization long before the possibilities of using SWFs in aid of these objectives arose in this century.").

356 For a critique, see e.g., Yllmaz Akyüz, Waving or Drowning: Developing Countries after the Financial Crisis, Geneva: South Centre, 2013.

357 See Julien Chaisse, Demystifying Public Security Exception and Limitations on Capital Movement: Hard Law, Soft Law and Sovereign Investments in the EU Internal Market, (2015). http://scholarship.law.upenn.edu/cgi/viewcontent.cgi?article=1912\&context=jil. Last visit: May 11, 2016. pp. 626-627 (emphasis added). 
As dominant and controlling shareholders act in public companies, it is normal to extract self-advantage. Since the new IF Is will have dramatically different dominant owners we can expect these new owners to quite naturally leverage their self-interest to the fullest. The question is not if but to what extent and how expeditiously the "newly civilized" will be able to make economic reforms and/or political change to suite their interests. The structure of transactions and corollary issues such as whether to incorporate environmental, ethical and other CSR topics, will impact on borrowers, lenders and stakeholders. With new architects and potentially conflicting goals, the impact on these issues will be felt. Important questions arise with respect to IFIs and financial regulation. What will the new architects influence be regarding environmental, social and human rights?

\subsubsection{International Economic Law, Dispute Resolution, Trade and} Investment Treaties

International trade agreements may encompass broader, geopolitical and concerns global governance contexts have always played a role in investment treaty law. ${ }^{358}$ The strategic implications are conceded: trade agreements with the U.S. are a form of "entrench[ing] the presence of the U.S. in the region." 359 Indeed, the impetus for the (currently abandoned by the U.s.) TPP was the drive to retain the U.s. lead in rule making so that Washington, rather than Beijing, to create the foundation for "21st-century trade rules," including standards on trade, investment, data flows and intellectual property." 360

Investment treaties and agreements were "[h]istorically conceived as an instrument to be used by developed, countries to protect their firms' investments against political risks ${ }^{361}$ which always played a role in investment

$35^{8}$ See Locknie Hsu, Regulatory Flexibilities and Tension Public Health and Trade-An Asian perspective (2015). pp.180-181. See also Gordon, K. and J. Pohl, 'Investment Treaties Over Time - Treaty Practice and Interpretation in a Changing World', OECD Working Papers on International Investment (OECD Publishing 2015) 9. http://dx.doi .org/10.1787/5js7rhd8sq7h-en. Last visit: May 11, 2016 ("noting nations have multiple reasons for signing BITS related to geo-political interests").

359 Id.

36o Andrew Hammond, The TPP Gives the U.S. - Rather than China - The Power to Influence Global Trade (2016). http://news.nationalpost.com/full-comment/andrew-hammondthe-tpp-gives-the-u-s-rather-than-china-the-power-to-influence-global-trade. Last visit: May 11, 2016 (emphasis added).

361 Julien Chaisse, Greek Debt Restructuring, Abaclat v. Argentina and Investment Treaty Commitments: the Impact of International Investment Agreements on the Greek Default, in 
treaty law. ${ }^{362}$ Self-interest drives law and economics ${ }^{363}$ and in some ways BITs are again reflective of the power differences between the "civilized" and the "non-civilized."

Like old capitulation agreements, present day BITs also exempt foreign investors from having to go to local courts. They merely substitute international arbitral mechanisms for the former's recourse to consular officials. Further, while investment agreements are formally the product of mutual state consent, the consent by LDCs to terms that are extremely favorable to foreign investors largely from the West has been heavily constrained by the dictates of the market as well as the privatization and other demands extracted by institutions like the World Bank and the IMF. ${ }^{364}$

But power is shifting and while the "developed" civilized nations had initially designed and shaped these instruments and institutions, the noncivilized nations have become economic powerhouses. Investment treaty law decisions ${ }^{365}$ _ including claims and defenses ${ }^{366}$ _ are impacted by and reference international law. ${ }^{367}$ The definition, contours and application of treaty

International Economic Law After The Clobal Crisis-A Tale of Fragmented Discipline. p. 308.

362 See Gordon, K. and J. Pohl (2015), Investment Treaties over Time-Treaty Practice and Interpretation in a Changing World, OECD Working Papers on International Investment, 2015/02, OECD Publishing. p. 9. http://dx.doi.org/10.1787/5js7rhd8sq7h-en. Last visit: May 11, 2016.

363 See Simon Lester, Should the United States Use Treaties to Make the World "More Like Us"? p. 4. http://www.vjil.org/assets/pdfs/vjilonline4/Lester-v5-MLM_POST-PRODUCTION_ PUBLISH_ONLINE.pdf. Last visit: September 12, 2017.

364 See José E. Alvarez, Contemporary International Law: An 'Empire of Law' or the 'Law of Empire.' 24 American University International Law Review 811 (2009), p. 827.

365 Inceysa Vallisoletana, S.L. v. Republic of El Sal., ICSID Case No. ARB/03/26, Award, 224 (Aug. 2, 2006), http://italaw.com/documents/Inceysa_Vallisoletana_en_oo1.pdf. Last visit: May 11, 2016.(noting stating the tribunal will apply rules and principles of international law). See also Christoph Schreuer, The Development of International Law by ICSID Tribunals, ICSID Review, (2016), p. 8. (noting tribunals apply international law).

366 See Christoph Schreuer, The Development of International Law by ICSID Tribunals, ICSID Review, (2016), p. 4. (noting the relevance of customary international law, human rights and treaties on arbitral rulings).

367 See Gordon, K., J. Pohl and M. Bouchard (2014), Investment Treaty Law, Sustainable Development and Responsible Business Conduct: A Fact Finding Survey, OECD Working Papers on International Investment, 2014/01, OECD Publishing. p. 21. http://dx.doi 
obligations will have different outcomes depending upon interpretations of international law. ${ }^{368}$ Thus, the terms and rules of international trade, the usage of certain dispute resolutions and the interpretations of disputes based upon international law are all potentially affected by the new architects since "investment tribunals should and actually do apply all, or major parts of, international law and not just a specialized segment." ${ }^{369}$

International law is becoming increasingly important in investment treaty law $^{370}$ and the new architects will have their own interests to advancenumerous issues will be affected. These issues include: debt restructuring, treaty commitments, sovereign defaults, whether certain conditions constitute an emergency or fiscal crisis (and thus override a treaty) are all subject to various international law that may change.

For example, pursuant to current international law, the ability to move capital across borders is considered fundamental. "[T] he free movement of capital is a fundamental freedom in the European common market, and as such can be restricted only in clearly limited cases." ${ }^{371}$ However, international law also allows "member states to restrict the movement of capital to or from other member states or third countries when given grounds as a matter of ensuring public order or public security."372 Will the new architects have a different view or will they continue to define public order and security as is presently defined since the new architects "will be increasingly dissatisfied with the current

.org/10.1787/5jzoxvgxızlt-en. Last visit: May 11, 2016. quoting Campbell McLachlan, The Principle of Systemic Integration and Article $37(3)(c)$ of the Vienna Convention, International and Comparative Law Quarterly, Vol. 54, Issue 2, (2005), p. 280. Thus, investment treaty law is increasingly referencing international law and the definition of such obligations will have different outcomes than in the current architecture.

368 Id., p.22.

369 Id. p. 9. Moreover, investment tribunals may also contribute to the development of international law. See id. See also Gilbert Guillaume, Can Arbitral Awards Constitute a Source of International law under Article 38 of the Statute of the International Court of Justice? in Yas Banifatemi (ed), Precedent in International Arbitration (Juris 2008) p. 105.

370 See Gordon, K. and J. Pohl (2015), Investment Treaties over Time-Treaty Practice and Interpretation in a Changing World, OECD Working Papers on International Investment, 2015/02, OECD Publishing. p. 38. http://dx.doi.org/10.1787/5js7rhd8sq7h-en. Last visit: May 11, 2016.

371 See Julien Chaisse, Demystifying Public Security Exception and Limitations on Capital Movement: Hard Law, Soft Law and Sovereign Investments in the EU Internal Market, (2015). http://scholarship.law.upenn.edu/cgi/viewcontent.cgi?article=1912\&context=jil. Last visit: May 11, 2016.

372 Id., p.613. 
Western-derived notion of international order." ${ }^{373}$ China has already stated that it has strong reservations regarding the existing Western rules. ${ }^{374}$

Sustainable development and corporate responsibility including human rights, anti-corruption, labor law, and environmental concerns. ${ }^{375}$ In recent years, sustainability and social responsibility have steadily increased ${ }^{376}$ and arbitrators have increasingly incorporated these factors into rulings. ${ }^{377}$

Specifically, 287 of the 1113 decisions surveyed mention at least one of these issues at least once-that is, $26 \%$ of the documents deal in some way with these $\mathrm{SD} / \mathrm{RBC}$-sensitive issues. The breakdown of references is as follows:

- The term "environment" occurs in 165 decisions;

- The term "human rights" is found in 131 documents;

- "Corruption" is referred to in 81 decisions, and "bribery" in 29 documents;

- References to "labour conditions", "labour standards" or "labour law" can be found in 2 decisions. A broader key word search on the term "labo $(\mathrm{u}) \mathrm{r}$ " produced 131 results. ${ }^{378}$

Corruption and bribery as a defense provide an excellent example of shifting interests since:

within the current state of international investment law, it has been relatively well settled that bribery/corruption is considered contrary to international public policy. The result has led arbitrators both within ICSID and other arbitral regimes to increasingly accept an affirmative defense commonly known as the "corruption defense" which allows tribunals to

373 Defense Technical Information Center (DTIC), p. 28. http://www.dtic.mil/doctrine/ concepts/joe/joe_2035_july16.pdf. Last visit: September 12, 2017.

374 http://www.fmprc.gov.cn/mfa_eng/xwfw_665399/s2510_665401/t1269971.shtml. Last visit: May 11, 2016.

375 See Gordon, K., J. Pohl and M. Bouchard (2014), Investment Treaty Law, Sustainable Development and Responsible Business Conduct: A Fact Finding Survey, oEcD Working Papers on International Investment, 2014/01, OECD Publishing. http://dx.doi.org/10.1787/ 5jzoxvgxizlt-en. Last visit: May 11, 2016.

376 Id.

377 Id.

378 Id. 
void an underlying contract if procured through an act of corruption or bribery. ${ }^{379}$

Yet it is the new architects that seemingly do not value bribery and corruption to the same extent.

While reporting to TRACE is voluntary and therefore inferences should admittedly be drawn with caution, in the countries of Brazil, China, India and Russia (the appropriately named BRIC countries) between $47-75 \%$ of respondents reported multiple bribe solicitations per year with $7-20 \%$ stating they received over 100 requests. ${ }^{380}$

As international law potentially undergoes a new architectural basis, investment treaty decisions may "evolve" to incorporate the norms of the new architects. $^{381}$

Right now, China wants to write the rules for commerce in Asia. If it succeeds, our competitors would be free to ignore basic environmental and labor standards, giving them an unfair advantage over American workers ... We can't let that happen. We should write the rules. ${ }^{382}$

Alternatively, trade may be reduced and nations may simply decide the irreconcilable differences militate towards pulling away from global integration and trade. Several new architects such as India and South Africa have considered withdrawing from investment treaties. ${ }^{383}$ As a corollary several of the

379 See R. Zachary Torres—Fowler, Undermining ICSID: How The Global Antibribery Regime Impairs Investor-State Arbitration (2012) pp. 998-999. http://www.vjil.org/assets/pdfs/ vol52/issue4/Torres-Fowler_Post_Production.pdf. Last visit: May 11, 2016.

$380 \quad$ Id.

381 For an excellent discussion of China and trade See Heng Wang, The RCEP and Its Investment Rules: Learning from Past Chinese FTAs, The Chinese Journal of Global Governance, Vol. 3, No. 2 (2017).

382 https://www.whitehouse.gov/blog/2015/02/18/president-obama-writing-rules-21stcentury-trade. (2015).

383 See Simon Chesterman. 
existing architects are also becoming less welcoming on investment treaties ${ }^{384}$ and trade pacts. ${ }^{385}$

\subsection{Discussion}

Some argue that the Chinese challenge will be rebuffed and the United States will remain the global hegemon for the remainder of the century. Indeed other nations have been considered as threats to the United States only to ebb. " $[\mathrm{H}]$ istory is filled with shocking miscalculations - the exaggerations of Soviet power in the 1970s and Japan's economic rise in the 80 ." $^{386}$

[T] here is no United States demise. For the rest of the 21st century the United States will remain the world's strongest military power, its most innovative economy and the chief defender of the core values on which our country was established. Our economy is the strongest it's ever been, our corporate sheets are the strongest they've ever been, our unemployment rate is at a record low, we have seen 15 million new jobs created and these are honest numbers, not numbers created by a party machine. ${ }^{387}$

But as described supra, the current prospect is different in several crucial aspects and a plausible potential exists that China and several key allies will indeed successfully challenge American supremacy. ${ }^{388}$

As the new architects benefit from the global power shifts, it is inevitable that the global governance orders-financial and legal-will undergo a transformation with ramifications in the international geo-political ${ }^{389}$ and economic battle-fields. This is neither surprising nor new-monetary power correlates positively with strategic success.

384 Australia, recently found itself on the receiving end of investor-state arbitration in the Philip Morris.

385 For example, see The Tran Pacific Partnership.

386 See Paul Kelly Centre Stage in the China-US Soft PowerCcontest.(2016). http://www .theaustralian.com.au/opinion/columnists/paul-kelly/centre-stage-in-the-chinaus-softpower-contest/news-story/1745ee5055ab97beo7faa621678cadc5. Last visit: September 12, 2017. (quoting former us Ambassador John Berry).

387 See Joseph Nye, https://www.project-syndicate.org/commentary/american-hegemonymilitary-superiority-by-joseph-s--nye-2015-03?barrier=true. Last visit: May 11, 2016.

388 See Supra Note 386.

389 See Simon Chesterman (noting that in recent years China has become substantially more active on the international political stage including exercising UNSC vetoes. 
There is nothing new in the idea that countries seek to turn financial capital into political power. Britain pursued the same approach in the $19 \mathrm{~h}$ century, and the United States has done so successfully since World War Two. ${ }^{390}$

China's strategic and long-term interest is fundamentally different form that of the Allies after ww2 and even its state-owned enterprises - which are significant economic actors both domestically and internationally-are expected to advance the Chinese national interest. This is not a purely speculative inquiry. China would like to influence the global political system and shape the universal values ${ }^{391}$ and may harbor an ambition to transform Western nations to its own norms and values. ${ }^{392}$ Referring to democracy as "flawed", China favors "an alternative political and economic system." ${ }^{393}$ Echoing these sentiments, an eminent Chinese jurist has urged judges to "absolutely" not embrace "false" Western concepts such as judicial independence, separation of powers and constitutionalism. ${ }^{394}$ By no means is this a critique of China since it simplybut is a realistic understanding - of what architects seek to advance. This would be no different than the United States pushing Western notions of rights and values onto developing nations.

Moreover, the potential exists that Western nations will seek to embrace the new powers as evinced by the failure of the U.s. to prevent key allies from joining the АIIв. ${ }^{395}$

Just as access to American markets and capital was once a key component of U.s. diplomacy, China is now employing its financial and trade muscle to win friends and influence. ${ }^{396}$

390 John Kemp, China's Silk Road Challenges U.S. Dominance in Asia (2014). http://www .japantoday.com/category/opinions/view/chinas-silk-road-challenges-u-s-dominancein-asia. Last visit: May 11, 2016.

391 https://www.bloomberg.com/politics/articles/2017-01-22/china-slams-westerndemocracy-as-flawed-as-trump-takes-office. Last visit: September 12, 2017.

392 Id.

393 Id.

394 https://www.ft.com/content/6odddd46-dc74-11e6-9d7c-be108ficıdce. Last visit: May 11, 2016.

395 John Kemp, China's Silk Road Challenges u.s. Dominance in Asia (2014). http://www .japantoday.com/category/opinions/view/chinas-silk-road-challenges-u-s-dominancein-asia. Last visit: May 11, 2016.

396 Id. 
This may substantially affect Western nations and their willingness to confront powerful states that do not share the current values. Pursuant to the United States led Western model of domestic government and global governance, governments are institutions could be critiqued without retribution and government control of individuals is viewed as a negative. ${ }^{397}$ However, once a new hegemon arises, incentive will expeditiously shift to engage in a spirit of alliance and leave the orbit of the existing hegemon. "China's economic dominance has broken into the Western alliance system, with countries from Japan to Australia eager for trade with China rather than to remain as ramparts for a Western military project." ${ }^{398}$ Moreover, demonstrating the fluidity of norms, Western nations, particularly post- $9 / 11$, have shifted towards the "noncivilized" notions of security arguing in favor of conduct once considered a clear violation of international law. ${ }^{399}$

Indeed, a large set of freedoms and rights taken for granted by the Western Euro-USA centric coalition of "civilized" nations may very well be "in play" in the context of international law created by the new architects. Many Western concepts are foreign or not acceptable to other nations. According to the new architects, Western imposed norms and rules translates into an international environment in which "no one feel(s) safe, because no one can feel that international law is like a stone wall that can protect them." 400

Further, while the narrative in recent decades has been that interaction with Western norms would help democratize China, perhaps this goal may in some sense be unethical since for example the Chinese seem satisfied with their current values and norms. ${ }^{401}$

397 Samuel Locklear and John Hamre, Don't Forget the National-Security Case for TPP Trade Deal http://blogs.wsj.com/washwire/2015/10/23/dont-forget-the-national-security-casefor-tpp-trade-deal/. Last visit: May 11, 2016.

398 Vijay Prashad, End of Exceptionalism. http://www.frontline.in/world-affairs/end-ofexceptionalism/article8811042.ece. Last visit: May 11, 2016.

399 Daniel Bethlehem, Principles Relevant to the Scope of a State's Right of Self-Defense Against an Imminent or Actual Armed Attack by Nonstate Actors', 106 American Journal of International Law (2012).

400 See Putin's Prepared Remarks at 43rd Munich Conference on Security Policy (2007). http:// www.washingtonpost.com/wp-dyn/content/article/2007/02/12/AR2007021200555.html. Last visit: May 11, 2016.

401 To be sure, a factor or partial cause of Chinese satisfaction may very well be the fact that China has made some movement towards a more Western outlook. China has made various attempts to improve their human rights record; each of its four constitutions (1954, 1975, 1978, and 1982) include an entire chapter on human rights. See Weatherly, 1999 at page 101). 
[T] he Chinese appreciation of democracy is different from the West. Dickson explained that most Chinese do not measure democracy with the rights that they exercise but with what they get from the government."

Moreover, despite Western critique, the majority of Chinese citizens perhaps do not mind censorship ${ }^{402}$ and appear to be satisfied with their Government. ${ }^{403}$ "86 percent of Chinese said they were content with their country's direction, double the percentage who said the same thing in 2002."404 This suggests that Chinese perceptions on rights and freedoms - while markedly different than Western - may be legitimate in China. ${ }^{405}$ If so, then is it impractical and perhaps unfair for the "civilized world" to impose a Western version of rights and freedoms on the "uncivilized"? Is it fair to presume modern Western values are the superior ones or at a minimum, norms that all nations must accept? This is reminiscent of the rationale "a country would not truly be civilized until it adopted and implemented legal reforms to create a Western-style legal system for all persons within its jurisdiction." ${ }^{406}$ Certainly, large scale dissatisfaction among the citizens of the current architects does not corroborate this presumption of superiority. Indeed, some argue that the "civilized" Europeans were in fact anything but barbaric.

Europe confessed itself impressed and was stung to emulation by the lofty magnanimity and the ideals of chivalrous honour presented to it by the knights of Spain, by gentlemen like the fierce soldier Al-Mansur who claimed that, though he had slain many enemies in battle, he had never offered an insult to any —an ideal of knightly demeanour and dignity which twentieth-century England might with profit emulate. The ruffi-

402 Ana Ablaza, New Book Explains Popular Support for China's Communist Party (2016). http://en.yibada.com/articles/165127/20161006/new-book-explains-popular-supportchina-s-communist-party.htm. (noting that very few Chinese object to censorship).

403 Id.

404 French, Howard W. 2008, Despite Flaws, Rights in China Have expanded, New York Times August 2nd 2008.

405 See Jack Donnelly, Human Rights and Human Dignity: An Analytical Critique of Non Western Conceptions of Human Rights, 76 AM. POL. SCI. REV. 303 (1982), p. 303 (arguing the intellectual underpinnings of human rights are Western concepts).

406 David P. Fidler, A Kinder, Gentler System or Capitulations? International Law, Structural Adjustment Policies, and the Standard of Liberal, Globalized Civilization, 35 Texas Journal International Law 387 (2000), p. 393. 
anly Crusaders were shamed by the grandeur of conduct and generosity of Saladin and his chivalry. ${ }^{407}$

Militating against rapid transformation and in favor of incrementally modifying the current order is the fact that China must deliver economic growth to its citizens and socialist models fail at doing so. For example, one of the great consequences of the last 50 years has been the detachment and autonomy of the private sector. It will be hard for China to put that genie back in the bottle. Furthermore, the rise of the new architects has been enabled by adherence to a market based formula. Free trade and a rights based system has empowered the new architects and some or many may have a vested self-interest continuing this path. For example, the rise in FTAs, the significant interest in TPP and RCEP all indicate a commitment to the existing governance infrastructure. Therefore these rising powers may seek to integrate and reform the current architecture to pursue their own interests and agenda ${ }^{408}$ and a selective modification of norm changes. ${ }^{409}$

The possibility also exists for the international law architects to stand firm and/or use their still superior power to limit the rise and influence of the new architects. ${ }^{410}$ Thus, pursuant to Western self-interest, the existing architects could attempt to limit the power of Confucian and Islamic states. ${ }^{411}$ After all, "in the long term, our [United States] security is best ensured by the success of our ideals: freedom, human rights, open markets, democracy and the rule of law"412 Doing so is not based upon an ethical or moral duty, but rather cold hard self-interest and would corroborate the claim that the current architects' idealistic notions are a self-serving contextual narrative. ${ }^{413}$ Of course having

407 Robert Briffault Making of Humanity https://archive.org/stream/makingofhumanityoobr ifrich\#page/19o/mode/2up page 307-08. Last visit: May 11, 2016.

408 John Ikenberry, The Future of the Liberal World Order: Internationalism after America, Foreign Affairs (2011), pp. 56-68.

409 See Simon Chesterman. (noting a possible "convergence of Western and Asian interests in the international order").

410 The failed attempt of the United States to thwart allies becoming members of the AIIB may have been such an attempt.

411 Samuel P. Huntington, The Clash of Civilizations? (1993). pp. 46, 49. https://www.foreign affairs.com/articles/united-states/1993-06-01/clash-civilizations,https://www.hks.harvard .edu/fs/pnorris/Acrobat/Huntington_Clash.pdf. Last visit: May 11, 2016.

412 Rice, Condaleezza, 'The New American Realism Foreign Affairs Vol 87 No. 4, 2008. p. 14.

413 See Robert Briffault, Making of Humanity, pp. 180-202. https://archive.org/stream/making ofhumanityoobrifrich\#page/19o/mode/2up. Last visit: May 11, 2016. (noting substantial 
reached a critical mass, the ability to limit let alone stop the new architects may no longer be feasible.

\section{Conclusion}

A nation's status as an architect (i.e. a powerful state) determines its influence on international law. The current international legal and financial governance order has been created, dominated and overseen by the United States-the indispensable global leader along with key strategic allies. This exceptional dominance has been institutionalized by the IMF and World Bank, supported by the enormous military power of the United States and backed by the world's premier reserve currency - the U.s. Dollar. All of these factors have entrenched the U.s. as chief architect of the global economic and legal architecture.

However, the world has changed over the last few years. No longer dominated and principally shaped by the current architects, new architects will likely attempt to-and will wield sufficient power to-affect international law. ${ }^{414}$

The situation of Asia is unique in that the states of the region have a majority of the world's population, the largest share of its landmass and are projected to overtake Europe and North America in economic output in the coming decades. For such a region to be predominantly a 'rule taker' is a problem that scholars have been trying to explain for some time. In particular, there does not appear to be a comparable example of a great power (or multiple powers) rising within a normative framework not of its own making, where that normative framework has not undergone substantial change or revolution as a result of the new power's values and interests. ${ }^{415}$

societal advancement in "Western Civilization" under the Islamic Caliphate, emphasis on education and literature).

414 U.s. Joint Chiefs of Staff, The Joint Force in a Contested and Disordered World, p. 52. http://www.dtic.mil/doctrine/concepts/joe/joe_2035_july16.pdf. Last visit: September 12, 2017.

415 Simon Chesterman, Asia's Ambivalence about International Law: Past, Present and Futures, (2016). https://academic.oup.com/ejil/article/27/4/945/2962207/Asia-sAmbivalence-about-International-Law-and. Last visit: September 12, 2017. 
This transformation will likely lead to re-writing the rules and will serve to devalue the institutions which have enforced the global governance architecture over the prior 70 years. At a minimum, the replacement of the present architects will present a definitional, let alone enforcement problem with respect to international law. A different code of conduct practiced by these new "civilized" or "leading" nations may conflict with current norms and international law will need to focus on this potential dichotomy between former and new standards and customs. The failure to address this impending clash of customs may lead to a fracture of global enforcement of international law, reduced prosperity and heightened conflict. 